\title{
Reading Comprehension and Strategy Use in Fourth- and Fifth- Grade French Immersion Students
}

Bailey Frid, The University of Western Ontario

Supervisor: Friesen, Deanna C., The University of Western Ontario

A thesis submitted in partial fulfillment of the requirements for the Master of Arts degree in Education

(c) Bailey Frid 2018

Follow this and additional works at: https://ir.lib.uwo.ca/etd

Part of the Bilingual, Multilingual, and Multicultural Education Commons

\section{Recommended Citation}

Frid, Bailey, "Reading Comprehension and Strategy Use in Fourth- and Fifth-Grade French Immersion Students" (2018). Electronic Thesis and Dissertation Repository. 5423.

https://ir.lib.uwo.ca/etd/5423

This Dissertation/Thesis is brought to you for free and open access by Scholarship@Western. It has been accepted for inclusion in Electronic Thesis and Dissertation Repository by an authorized administrator of Scholarship@Western. For more information, please contact wlswadmin@uwo.ca. 


\begin{abstract}
The Simple View of Reading (Hoover \& Gough, 1990) assumes that reading comprehension success is determined by decoding skill and language comprehension (e.g., vocabulary). However, the strategies readers recruit during text comprehension should also uniquely contribute to reading comprehension success in both their first and second language. Seventy fourth- and fifth-grade French immersion students were assessed on language proficiency measures and on strategy use during a reading comprehension task by using a think-aloud procedure. Results indicate that students used more complex strategies (i.e., background knowledge, predicting and visualizing) in their dominant language, and more textbase strategies (i.e., summarizing) in their less proficient language. For both languages, using textbase and complex strategies each accounted for unique variance in reading comprehension performance beyond language proficiency. Relying on these strategies allow readers to both construct an understanding of a text and consolidate it into memory. Implications for second language teachers will be discussed.
\end{abstract}

\title{
Keywords
}

French immersion, bilingualism, reading comprehension, reading fluency, vocabulary 


\section{Acknowledgments}

I would first like to thank my supervisor, Dr. Deanna Friesen, for her continued support and guidance throughout my master's experience. I would also like to acknowledge the women I have met in this program as well as my colleagues in the bilingual reading lab. I am grateful to have been able to connect with such encouraging women.

I cannot thank my parents enough. Gail and Larry Frid, thank you for your love and support over the last two years and for having all the confidence in me throughout my educational experience. Lastly, I would like to thank my siblings, Jaydon and Ally Frid, for your support and faith in my decisions throughout this process. I couldn't have done it without you. 


\section{Table of Contents}

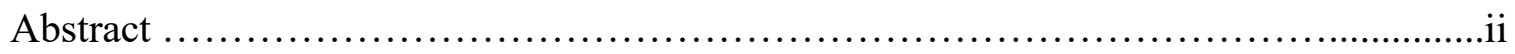

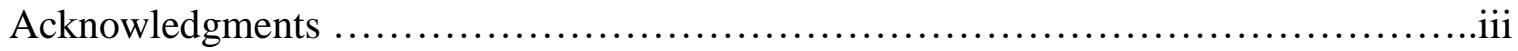

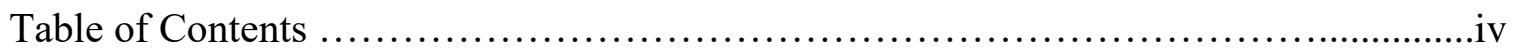

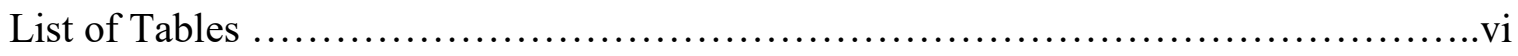

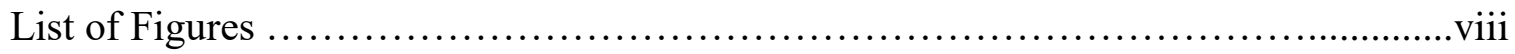

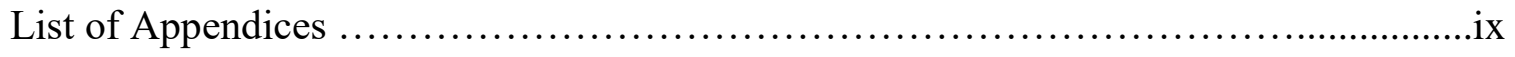

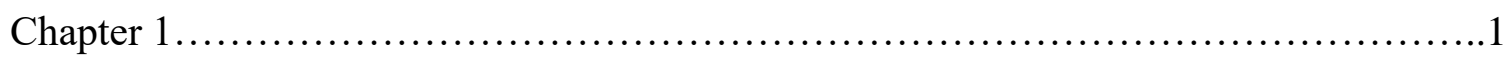

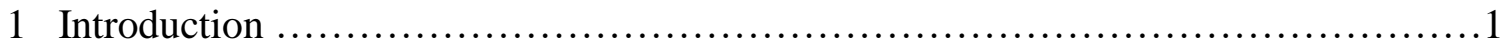

1.1 French Immersion Education......................................

1.2 Predictors of Reading Comprehension Success........................4

1.2.1 Simple View of Reading Model .......................5

1.2.2 Vocabulary Knowledge..............................6

1.2.3 Word Reading Fluency............................

1.2.4 The Construction-Integration Model....................9

1.3 Strategy Use................................................... 9

1.3.1 Strategy Use Within Monolingual Research..............11

1.3.2 Strategy Use Within Bilingual Research...................11

1.3.3 Strategy Use Protocols..............................13

1.4 Present Study................................................... 15

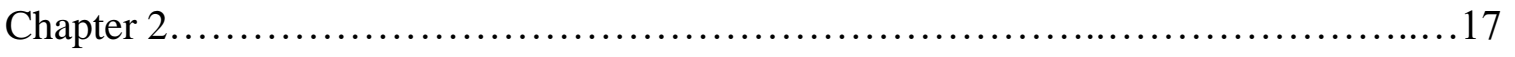

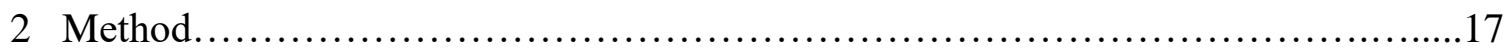

2.1 Participants...................................................... 17

2.2 Measures................................................................ 17

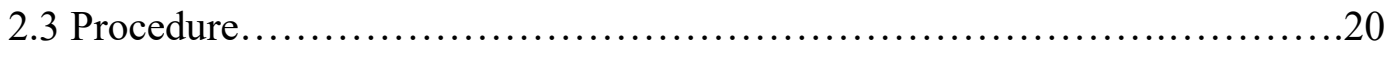

Sessions....................................................20

Think-Aloud Data Coding..........................................21

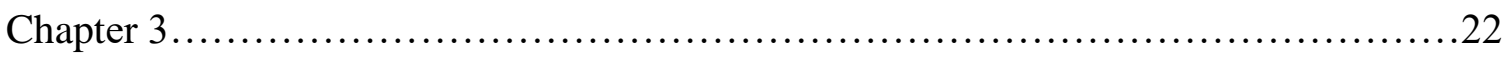

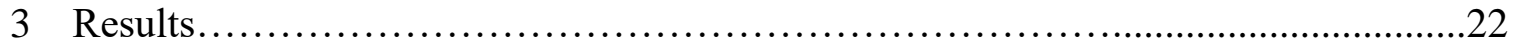

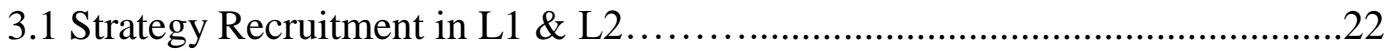


3.2 Language Proficiency \& Strategy Use as Predictors of Reading

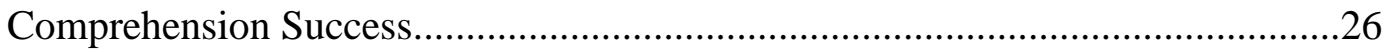

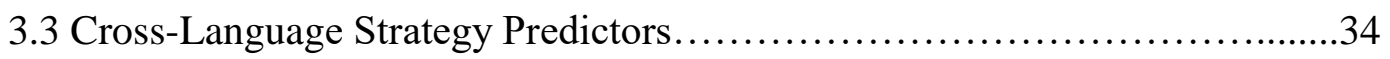

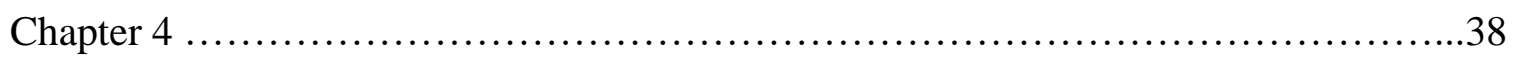

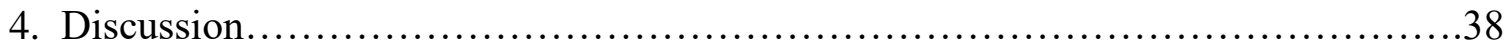

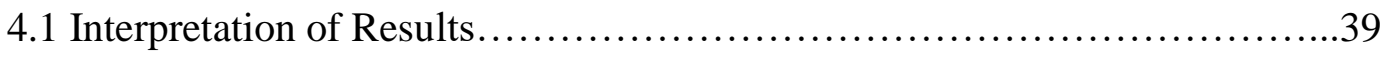

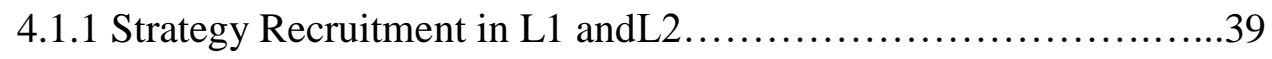

4.1.2 Language Proficiency and Strategy Use as Predictors of Reading Comprehension Success ........................................... 40

4.1.3 Cross-Language Correlations in Strategy Use......................43

4.2 Implications for French Immersion Educators..............................44

4.3 Limitations and Future Directions...................................... 47

4.4 Concluding Remarks................................................... 49

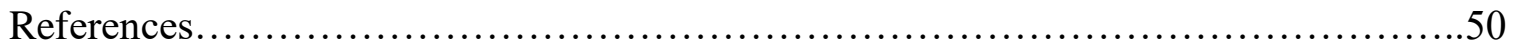

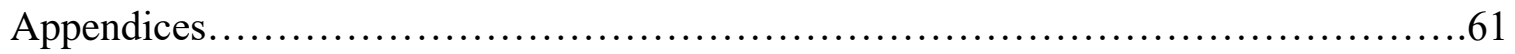

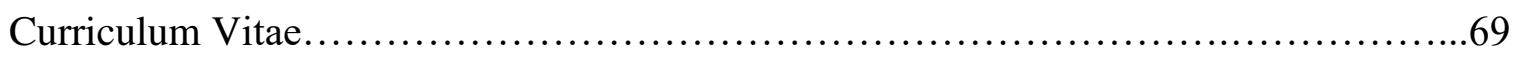




\section{List of Tables}

Table 1: Means and Standard Deviations of Number of Times Each Strategy was

Employed in Each Language.

Table 2: Means and Standard Deviations of Each Group of Strategies in Each

Language. .24

Table 3: Means and Standard Deviations for Language Measures in both English and

French .26

Table 4: Coefficient Table of English Variables that Predict Successful English Reading

Comprehension (Strategies ae Analyzed Independently).

Table 5: Coefficient Table of English Variables that Predict Successful English Reading

Comprehension (Strategies are Analyzed in Construction-Integration Model

Groupings) .28

Table 6: Coefficient Table of French Variables that Predict Successful English Reading Comprehension (Strategies ae Analyzed Independently).

Table 7: Coefficient Table of French Variables that Predict Successful French Reading Comprehension (Strategies are Analyzed in Construction-Integration Model

Groupings) .30

Table 8: Coefficient Table of French Variables that Predict Successful French Reading Comprehension (Strategies ae Analyzed Independently). .31

Table 9: Coefficient Table of English Variables that Predict Successful French Reading Comprehension (Strategies are Analyzed in Construction-Integration Model 
Table 10: Correlations between Each Individual Strategy between English and

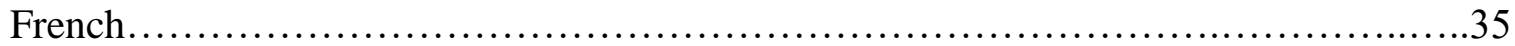




\section{List of Figures}

Figure 1: Proportion of each strategy type used in (a) English and (b) French think-

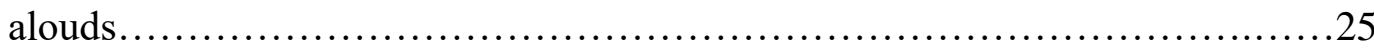

Figure 2: Proportion of each grouped strategy type used in (a) English and (b) French

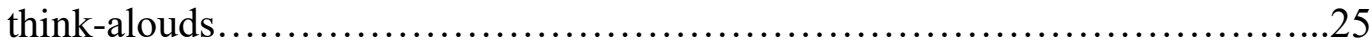

Figure 3: This figure shows that English RC performance can be predicted using a linear equation from a combination of scores on several predictive measures....

Figure 4: This figure shows that French RC performance can be predicted using a linear equation from a combination of scores on several predictive measures...........34

Figure 5: Cross-language/within-language English strategy recruitment .....................36

Figure 6: Cross-language/within-language French strategy recruitment.................37 


\section{List of Appendices}

Appendix A. Parent/Guardian Questionnaire...................................61

Appendix B: Peabody Picture Vocabulary Task..................................64

Appendix C: Reading Comprehension Task ..................................65

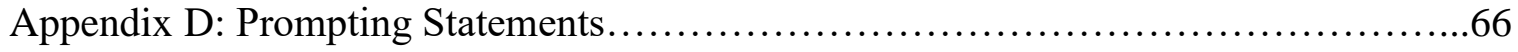

Appendix E: Ethics Approval..............................................67

Appendix F: Example of Think-Aloud Coding................................68 


\section{Chapter 1}

\section{Introduction}

Bilingualism can be defined as the ability to communicate and comprehend in two different languages (Baker, 2001). Bilingualism is important, especially in Canada, since there are two official languages, English and French. According to Statistics Canada, the population of English-French bilinguals in Canada has increased from approximately 650 000 individuals in 1901 to approximately 5.1 million in 2011. Canada values bilingualism by offering to educate its citizens in both languages through French immersion programs. Consequently, many individuals are learning to read and write in a language other than the one they speak at home (Jared, Cormier, Levy, \& Wade-Woolley, 2011). However, little is known about how French immersion programs prepare their students in becoming effective bilinguals and the practices they focus on when teaching important skills such as reading comprehension.

\subsection{French Immersion Education}

Parents of elementary-aged children must make a crucial decision about whether to send their child to an English-only school or an immersion program. French immersion programs are extremely popular. In a census conducted by Statistics Canada (2017), there was an increase of approximately 72000 elementary-aged students that are currently enrolled in French immersion programs between the years of 2011 and 2016. This increase in enrollment has resulted in a need for more French immersion teachers (Karsenti, Collin, Villeneuve, Dumouchel \& Roy, 2008). This popularity may be due to the perceived benefits of an immersion program. Parents may believe that enrolling their young learners in French immersion will get their child ahead of other learners in non- 
immersion program. Being able to communicate in more than one language is desirable in Canada because of the country's diverse population (Bournot-Trites \& Tellowitz, 2002). A bilingual education may result in English-French bilinguals having more job opportunities or being considered for jobs over their monolingual counterparts (AuYeung et al., 2014).

French immersion programs were first introduced in Canada in the 1960s with the purpose of teaching English-speaking students the French language (Genesee, 1984). French immersion supports the development of French oral language, reading and written skills in English-speaking students at little to no detriment to their English language and literacy development (AuYeung et al., 2014). Students who are enrolled in French immersion at an early age (i.e., kindergarten) are considered early immersion students. These early immersion learners show a shift in their L2 literacy to L1 literacy, which is notable since French immersion students often do not receive English instruction until fourth-grade (Genesee, 2004). The fact that they can excel in L1 reading without having exposure until a later age is impressive and contributes to the idea that French immersion does not negatively affect English language learning.

Immersion classrooms create an environment for sustained L2 exposure and authentic communication more than most other types of L2 classrooms (Lyster, 2004). Furthermore, immersion provides a classroom context allowing L2 learning by exposing students to $100 \%$ French instruction at the beginning of kindergarten and slowly introducing English language arts in grade 4 until students are receiving 50\% input of each language by eighth-grade (Au-Yeung et al., 2014). French immersion programs differ from core French programs in several ways. Firstly, core French programs teach 
French for 30-40 minutes starting only at fourth-grade. Next, research has shown minimal improvement in students' French proficiency in core French education. In contrast, research has shown notable improvements in students' French proficiency in French immersion programs (Cummins, 2014). Finally, results for core French programs have been disappointing since only $3 \%$ of Ontario ninth-grade core French students continue with the program until twelfth-grade (Canadian Parents for French, 2008).

Immersion students are taught in a way that encourages bilingualism and creates an environment that produces emergent bilinguals. Emergent bilinguals are individuals that acquire a L2 through various domains (i.e., school, community, etc.), become bilingual, and are able to continue to function in their home language as well as in their first-language (L1) (Garcia \& Kleifgen, 2010). Within this particular study, French immersion programs have been analyzed because of the additive bilingual environment, which encourages the development of existing L1 knowledge with the addition of French learning. Additive bilingualism refers to the learning of a L2 without detriment to the development of a L1 (Cummins, 1998).

Despite the benefits of bilingualism, Geva and Clifton (1994) found a lag in French reading comprehension amongst French immersion students when compared to English readers in English-only programs. Since students in French immersion are taught solely in French during their first few years, we might expect them to have comparable reading comprehension skills to monolingual English readers. Malicky, Fagan and Norman (1988) found that early immersion students are less able to integrate background knowledge when reading in French than in English. Even though French immersion programs are in place to transform students into young bilinguals, something is missing in 
the research that investigates reading comprehension instruction. It is important to understand the differences in L1 and L2 reading comprehension abilities among French immersion students.

Although we know that French immersion students struggle with reading comprehension in their $\mathrm{L} 2$ relative to their $\mathrm{L} 1$, little is known about the strategic processes that these students use in each language and how these processes relate to their comprehension success. This current study tested fourth and fifth-grade French immersion students on their language proficiency and reading proficiency. Of interest is how students in French Immersion engage in reading comprehension in both their first and second languages and how they recruit mental processes (i.e., reading strategies) to facilitate their comprehension in both languages. These students are of interest because in fourth- and fifth-grade, students are "reading to learn" rather than "learning to read", so the curriculum is comprehension-focused (Burstall, 1975; Grinder, Otomo \& Toyota, 1962; Snow \& Hoefnagel-Hohle, 1978). The inclusion of fourth- and fifth-grade French immersion students will help further research within the French immersion domain and determine language comprehension abilities of young people in their L1 and L2. Fourthand fifth-grade students are required to have the skills needed for successful comprehension and these skills include strategy use, language knowledge and reading decoding.

\subsection{Predictors of Reading Comprehension Success}

According to van den Broek and Kremer (2000), reading comprehension involves the recall of information from a text by extracting important themes, engaging in higher order thinking skills, constructing a mental image of the text, and understanding the 
structure of the text. Reading comprehension success is crucial early in education because building this foundation at a young age will likely translate to good reading comprehension later in life as well as academic success (Melby-Lervag \& Lervag, 2014).

Research completed with bilingual individuals has investigated reading comprehension in one's L1 and L2. Results have shown that similar predictors (i.e., vocabulary knowledge and reading fluency) relate to comprehension in both languages (Grant, Gottardo \& Geva, 2012; Lipka \& Siegel, 2012). For example, language comprehension in a target language is related to reading comprehension in that language (e.g., English vocabulary knowledge is related to English reading comprehension). Several theories exist that explain the factors that contribute to successful reading comprehension. Here I will examine two: the Simple View of Reading (Gough \& Tunmer, 1986) and the Construction-Integration model (Kintsch, 1988, 2005).

\subsubsection{Simple View of Reading model. Gough and Tunmer (1986) proposed the} Simple View of Reading model. Their model takes the form of an equation (i.e., $\mathrm{R}=\mathrm{D} \mathrm{x}$ C). $\mathrm{R}$ represents reading comprehension, $\mathrm{D}$ represents decoding and $\mathrm{C}$ represents language or listening comprehension. Furthermore, this model expresses the idea that reading comprehension success is a product of decoding ability and language/ listening comprehension (Hoover \& Gough, 1990). Both components are necessary but not sufficient to be a successful comprehender, such that an absence of one will result in a poor comprehension. Genesee and Jared (2008) also highlight the importance of studying reading fluency since it has an impact on decoding ability. Romney, Romney and Menzies (1995) determined that students are practicing little to no French reading outside 
of school, which likely negatively impacts the development of their French vocabulary knowledge as well as their word reading fluency.

1.2.2 Vocabulary knowledge. Research has often used vocabulary knowledge as a proxy for language ability. It is also crucial for effective reading comprehension. Receptive vocabulary knowledge has been measured using the Peabody Picture Vocabulary Test (PPVT; Dunn \& Dunn, 1997), which presents participants with four images and a word presented aloud. Participants must determine the picture that best matches the word (Bialystok, Peets \& Moreno, 2014; Chung, Koh, Deacon \& Chen, 2017; Lervag \& Aukrust, 2010). Past research has shown that individuals with stronger vocabularies recall more information overall and make fewer errors on story recall than individuals with weaker vocabularies (Fitzgerald \& Spiegel, 1983; Chu, 2016).

To investigate which pre-requisite language skills (including vocabulary) support L1 and L2 reading comprehension and transfer across languages, Jared et al. (2011) conducted a longitudinal study that looked at French immersion students. Participants were first tested in kindergarten and then yearly to third-grade. Grammatical ability, rapid naming, letter-naming and letter-sound knowledge in first-grade English were related to French reading comprehension in third-grade. Vocabulary knowledge was a languagespecific predictor. In other words, English vocabulary knowledge predicted English reading comprehension and French vocabulary knowledge predicted French reading comprehension. These findings support the Simple View of Reading model since both language knowledge (i.e., vocabulary) and decoding skills (e.g., rapid naming, lettersound knowledge) were predictors of reading comprehension. 
Lervag and Aukrust (2010) found that differences in students' L1 and L2 reading comprehension level could be due to differences in vocabulary knowledge. This study was not completed with immersion students but still shows the importance of vocabulary knowledge as a predictor of reading comprehension success. In this longitudinal study, reading comprehension and vocabulary was measured in second-grade students, where half had Norwegian as their only language and half had Urdu as their first language and Norwegian as their second language. Beginning reading comprehension skills in Norwegian were predicted by vocabulary and decoding skills in both L1 and L2 learners. Individual differences in decoding predicted reading comprehension skills but vocabulary appeared to be a stronger predictor of $\mathrm{L} 2$ reading comprehension than $\mathrm{L} 1$ reading comprehension. Therefore, vocabulary and decoding skills are both important to address when evaluating one's L2 reading comprehension success.

\subsubsection{Word reading fluency. Reading fluency refers to time-based measures of} accurate word reading scored as reading speed and reading accuracy (Jenkins, Fuchs, van den Broek, Espin \& Deno, 2003). The Test of Word Reading Efficiency (TOWRE; Torgesen, Wagner, \& Rashotte, 1999) has been used to measure word reading fluency (Harlaar, Dale \& Plomin, 2007; Lervag \& Aukrust, 2010; Lipka \& Siegel, 2011). In this measure, a list of words and non-words are presented, and participants are asked to read each list as fast and accurately as possible in 45 seconds. The speed and accuracy that contributes to reading fluency affects reading comprehension outcomes because fast and accurate word reading facilitates reading comprehension by releasing a reader's cognitive resources (i.e., working memory) to focus on meaning (Wolf \& Katzir-Cohen, 2001). Therefore, slow and inaccurate readers are spending more time trying to decode the text 
(Stevens, Walker \& Vaughn, 2017). For example, Proctor et al. (2005) assessed Spanishspeaking fourth-grade English language learners on decoding fluency, alphabetic knowledge, vocabulary and listening comprehension. Faster reading times were associated with better reading comprehension.

Recently, Erdos, Genesee, Savage and Haigh (2014) looked at L2 reading and oral language development in English-speaking students in an early total French immersion program in Montreal, Canada. The purpose of this study was to assess the validity of L1 predictors of L2 reading and oral language abilities. In the fall and spring of Kindergarten, they tested children on different language and reading measures: vocabulary, decoding, language fundamentals, etc. Reading tasks such as the TOWRE and Wechsler Individual Achievement Test were used to measure these abilities. They retested the students in the spring as they entered first-grade to determine whether the kindergarten assessments were predictors of first-grade performance. Decoding fluency was the best predictor of reading comprehension. This study provides support for the relationship between reading decoding, or fluency, and reading comprehension.

The Simple View of Reading assumes that reading success is solely determined by language comprehension and decoding ability. It is important to note that the above studies have analyzed predictors of reading comprehension by obtaining a single score on a reading comprehension measure. However, they do not consider what readers are doing during text construction itself. The current study looks directly at students' engagement with the text by examining the mental processes they recruit during a reading task. This could give insight into the specific behaviours (i.e., strategy use) that can also explain success beyond language measures. 
1.2.4 The Construction-Integration model. Kintsch (1988) proposed a model that combines constructive processes and integrative processes to explain what is occurring during the development of text representation. This model is a widely accepted theory in the majority of reading comprehension research (Britton \& Graesser, 2014; Reutzel, 2016; Stadtler \& Bromme, 2014). The Construction-Integration model provides a framework that combines the information in a text with the reader's literacy knowledge and background knowledge (Kintsch \& Welsch, 1991). This differs from the Simple View of Reading, which explains how language knowledge predicts reading comprehension rather than the strategies readers must undertake in order to tackle a text.

When a mental model of the text is being created there are three levels of text representation: the surface form, the text-base and the situation model. The surface form refers to information presented that can be perceived by the reader and is the literal wording of the text (McDonald \& Heilenman, 1992). The next level is the text-base, which is when the reader attaches meaning to the words and develops an understanding of the text itself. Lastly, situation models are created through the integration of the text-base with the reader's background knowledge (Zwaan \& Radvansky, 1998). Construction is the production of a text-base that is created from the linguistic input and the reader's knowledge base. Integration is the phase in which the text is amalgamated into a comprehensible whole. Ideally, a reader is able to form a comprehensive situation model of a text during reading comprehension. Presumably, in order to create a successful mental representation of the text, readers need to engage in strategic processes both to understand what they are reading and to determine what information to focus on.

\subsection{Strategy Use}


According to Afflerbach, Pearson and Paris (2008), strategy is defined as a conscious and systematic plan. Furthermore, a reading strategy is the mental systematic plan undertaken when interacting with a text. The mental processes one practices while reading is important to consider when discussing comprehension. Without this knowledge, it is unclear how individuals successfully comprehend what they are reading. Defining particular strategies can allow researchers to investigate the underlying mental activity taking place during the process of comprehension rather than solely examining the language predictors of successful reading comprehension. Strategies can include (i) summarizing - paraphrasing what was just read, (ii) inferencing - extrapolating something based on the text or reading "between the lines", (iii) predicting - making a hypothesis about what is to come, (iv) using background knowledge- remembering previous information from the story or from previous knowledge to understand the context of the text, or (v) questioning - asking questions about the text (Blachowicz \& Ogle, 2017; Coiro \& Dobler, 2007). The strategies individuals employ while reading may lead to their reading comprehension success.

Determining the strategies children use while reading can help researchers and educators determine the manner in which young readers try to understand the meaning of a text. At the elementary level, educators teach through modeling but should be guiding their students to develop independent reading (Friesen \& Haigh, 2018). Understanding the specific strategies that predict successful English or French reading could inform French immersion educators on the appropriate strategies to target in a reading comprehension lesson to improve students' comprehension skills. Transfer may be observed as well, which means teachers may be inclined to focus on a specific English 
reading strategy to improve students' French reading comprehension success and vice versa. The ultimate goal is to help students develop into successful English and French readers in the French immersion system. Gaining this knowledge of strategy use could indeed support this goal.

1.3.1 Strategy use within monolingual research. Baier (2005) determined that 14 sixth-grade English-speaking students who used reading comprehension strategies during a reading comprehension task retained more information and understood the text better than those who did not recruit strategies. Muijselaar et al. (2017) also tested reading comprehension and reading strategy use. Dutch-speaking fourth-graders were tested on reading comprehension. Knowledge of reading strategies was tested using the Reading Comprehension Questionnaire, which incorporated questions about monitoring strategies, comprehension strategies and reading strategies. Reading fluency was measured as well as vocabulary knowledge. Students who had knowledge of reading strategies had better reading comprehension scores. However, this study did not measure the actual use of strategies, only the knowledge of how and when to use strategies.

\subsubsection{Strategy use within bilingual research. A study by Uhl-Chamot and El-}

Dinary (1999) concluded that good bilingual learners may monitor and adapt their strategies, whereas poor learners stick with ineffective strategies. In this study, students in kindergarten to sixth-grade participated. Participants were taken from total French or Spanish immersion as well as partial Japanese immersion programs. The interest of this research was on learning strategies. Teachers rated their students as low or high-rated learners using a questionnaire that incorporated items about their L2 verbal and reading abilities. All participants completed two tasks to determine their L2 skill level. The first 
one was a writing task that required participants to complete a picture puzzle. The second task was a reading task that required participants to read excerpts in grade-appropriate texts in their second-language. While they worked they were given several opportunities to conduct a think-aloud. A think-aloud is a method that requires the participant to express what they are thinking about aloud. The researchers asked open-ended questions that needed to be answered aloud and the researcher also requested clarification and elaboration if necessary. In both tasks it was determined that low-rated learners used more decoding and high-rated students used background knowledge strategies that include necessary inferencing, elaborative inferencing and predicting. This study presented the notion that children as young as kindergarten can describe their thinking process in detail and students with differing L2 abilities recruit different strategies during a think-aloud task to support their reading and writing.

Jimenez, Garcia and Pearson (1996) conducted a study with 14 sixth- and seventhgrade Latino/a and Anglophones students. They varied in language proficiency and were categorized as Latino/a students who were successful English readers, Latino/a students who were somewhat successful English readers, and non-Latino/a students who were English monolinguals. The students conducted think-alouds while completing reading tasks in English and Spanish. The researchers coded responses and defined their verbalizations as reading strategies. The strategies were predetermined by the researchers and categorized into 3 groups (i.e., text-initiated - summarizing, vocabulary identification, rereading; reader-initiated - inferencing, questioning, predicting; and interactive -visualizing, cognate status, translating). Latino/a students who were successful English readers recruited specific strategies that differed from the other two 
groups. These strategies include monitoring comprehension through identifying unfamiliar vocabulary, identifying cognates between languages and translating. Successful Latina/o readers used less background knowledge while reading in Spanish than while reading in English. They also identified more unknown words in Spanish than in English. Furthermore, reading in Spanish appeared to be a more difficult task than reading in English. This may be due to the infrequent opportunities to read material in Spanish than in English. In this study, reading comprehension was not evaluated, which is the main focus of the current research. A think-aloud would be relevant to include along with a reading comprehension task to determine the thought-processes underlying an individual's attempt to understand a body of text.

1.3.3 Strategy use protocols. In order to determine an individual's thought-process during reading, self-report measures have been utilized (Uhl-Chamot, 2004). Think-aloud processes have been used to examine strategies recruited during a reading task. Lytle (1982) described the think-aloud process as an approach based on responses that reflect what a reader is doing at a particular point in time in order to understand what he/she is reading, and the strategies used to solve a particular problem with comprehension. Past research that has investigated strategy use through think-aloud procedures have been able to determine strategy complexity. For instance, findings have provided evidence that proficient bilingual readers use more complex strategies during a comprehension task such as elaborative inferences and analyzing text format (Meyers et al., 1990; UhlChamot \& El-Dinary, 1999). However, proficient readers with less aptitude in French may utilize strategies to compensate for their lack of language knowledge such as summarizing. 
This current research incorporated a think-aloud protocol to determine the frequent strategies used during successful comprehension. A think-aloud requires participants to describe what they are thinking about as they read. Metacognitive theory provides a conceptual framework for think-aloud procedures. This theory suggests that one's knowledge of his or her own cognitive processes may be a significant component of the learning process and that instruction can be facilitated by increasing awareness of his or her own learning strategies (Meyers et al., 1990).

Scaffolding strategy use during a reading task has been shown to improve students' comprehension (Kim \& White, 2008). Past researchers have carried out distinct techniques that include: picture cues, which requires the researcher to prompt the participant with images (Bowen \& Howie, 2002; Saywitz \& Snyder, 1996), verbal cues, which requires the researcher to prompt the participant with verbal questions (O'Shea, Sindelar \& O'Shea, 1985), or strategy cues, which requires the researcher to prompt the participant with strategies verbally or written (Babbs, 1984). These techniques were set in place to assist individuals with story recall and successful comprehension. In a study by Proctor, Dalton and Grisham (2007), fourth-grade Spanish-speaking ELLs in the USA were asked to complete an English reading comprehension task on a computer. Throughout the reading they were prompted with specific reading strategies (i.e., predicting, summarizing, questioning, etc.). When prompted, they were required to type out their response to the strategy cue. Participants' reading comprehension was scored prior to the start of the study and again, after the prompting condition. The purpose of this procedure was to determine whether prompting influenced comprehension, not necessarily the specific strategies that predicted comprehension success. The researchers 
concluded that students' reading comprehension improved when presented with strategy prompts. Also, students who were less skilled readers were likely to engage with the strategy cues more often than more skilled readers. For the purpose of this current research, strategy cues were used. Participants were presented with a list of sentence starters that resembled specific strategy cues and were encouraged to interact with the list and use the phrases during the think-aloud process.

\subsection{Present Study}

The purpose of this research is to determine the strategies emerging bilinguals choose to recruit when reading in their L1 and L2 in order to successfully comprehend a reading passage. This current study is intended to fill the gaps in previous reading comprehension research that neglected to focus on the specific mental processes emergent bilinguals are recruiting when interacting with a text. This information will build on existing research and provide a better understanding of the differences in reading comprehension success within French immersion students' English and French reading. This current research will take into account the findings relating language knowledge and reading fluency to reading comprehension success as well. Not only will this research investigate predictors of reading comprehension within a specific language, it will also look at cross-language findings. Transfer, skills assessed in English that can predict French comprehension performance and vice versa, has been observed in previous research (Comeau, Cormier, Grandmaison \& Lacroix, 1999; Jared et al., 2011). This will inform researchers and French immersion teachers on the specific strategies that impact reading comprehension between languages and within a language. 
The specific research questions include (1) What type of reading comprehension strategies do emergent bilingual children in French Immersion use when processing texts? (2) Do emergent bilingual children engage in similar reading strategies in both their first and second languages? (3) What role does vocabulary knowledge, reading fluency and strategy use play in successful reading comprehension? (4) Can strategy use in one's L1 predict strategy use in their L2 and vice versa?

It is hypothesized that (1) Children will use different strategies in the English and French reading task. As discussed in the paper by Jimenez, Garcia and Pearson (1996), students use different strategies to support their reading in their L1 and L2. (2) Children will use more elaborative and complex strategies when reading in their first language since their L1 is their stronger language. Recruiting more situation model strategies in one's stronger language has been shown in previous research (Jimenez, Garcia \& Pearson, 1996; Uhl-Chamot \& El-Dinary, 1999) (3) Vocabulary knowledge, reading fluency and complex strategy use are expected to predict reading comprehension success. Vocabulary knowledge and reading fluency have been shown to be predictors of successful reading comprehension in one's L2 (Lervag \& Aukrust, 2010). Past research has shown that strong bilingual readers use more complex strategies (i.e., elaborative inferencing, text analysis) to support their comprehension (Meyers et al., 1990; UhlChamot \& El-Dinary, 1999). Importantly, for this study is whether strategies account for unique variance above and beyond language proficiency. (4) Strategies used in one’s L1 will also be recruited in their L2 and vice versa. Previous research has shown elements of reading in French immersion students (i.e., phonological awareness) transfer between languages (Trites \& Price, 1978; Deacon, Wade-Woolley \& Kirby, 2007). Cummins 
(1991) describes an interdependence hypothesis that posits the relationship between the L1 and learning an L2. The common underlying proficiency model is the basis for the hypothesis and this states that the proficiencies involving more cognitively demanding tasks (i.e., literacy) are common across languages. Language that is used in more cognitively demanding tasks, such as a reading comprehension task, involve more complex language, which is transferable across languages.

\section{Chapter 2}

\section{Method}

\subsection{Participants}

Seventy-three fourth- and fifth-grade French Immersion students from a large school board in Southern Ontario were recruited to participate in the study. Three participants were removed from analysis due to incomplete data (i.e., inability to complete a task without help from the researcher). Within this sample of 70 participants $\left(M_{\text {age }}=10.36(6.9)\right.$ years, 44 females $), 66$ of the students spoke English as a first language. Participants spent an average of 5.2 years in the French immersion program. These emerging bilingual students were able to read and understand content in French and English. Participants' parents reported their children spent an average of 5.61 (3.8) hours reading in English outside of school per week and 2.27 (1.0) hours reading in French outside of school per week. All students had normal or corrected-to-normal vision.

\subsection{Measures}


Language Experience Questionnaire. Language experience was assessed using a Parent/Guardian Questionnaire. The questionnaire was modelled after the Language and Social Background Questionnaire (LSBQ) developed by Anderson et al. (in press). The questionnaire included items on the participant's understanding and reading in English and French, each parent's experience with both languages, and the participant's motivation to read in each language (see Appendix A).

Receptive Vocabulary Knowledge. Vocabulary knowledge was assessed using the Peabody Picture Vocabulary Test (PPVT-III; Dunn \& Dunn, 1997). The PPVT is a receptive vocabulary task. Participants were presented with 4 images on a computer screen (see Appendix B for an example) and an audio recording of a word played simultaneously with the images. The participant is required to select the picture that best matches the word. The starting point of the task is determined by the participant's age and sets of items increase in difficulty. The participant's basal level is determined by making fewer than 2 errors in a set of 12 items. If participants make more than 2 errors, they are dropped down to an easier set. Once the basal is determined, a stop rule is applied when participants make 8 errors in a set of 12 items. The PPVT score was determined by adding correct answers to total number of items from the uncompleted basal blocks. Version A was completed in English and Version B was completed in French.

Word Reading Efficiency. English word reading efficiency was assessed using the Test of Word Reading Efficiency (TOWRE; Torgesen, Wagner, \& Rashotte, 1999). A French version created by Jared et al. (2011) was adopted for use in this study. The TOWRE includes two lists. One is a list of 104 real words and the second list is comprised of 63 non-words. Non-words follow legal orthographic patterns and can be 
read using the target language's spelling-sound correspondence without any semantic meaning. Participants were required to read aloud lists as quickly and as accurately as possible. For each list, participants were given 45 seconds and were audio-recorded for coding purposes. The TOWRE was scored by subtracting the number of incorrectly pronounced words to the correctly pronounced words, which resulted in the total number of correctly pronounced words. This task was completed in English and in French.

Reading Comprehension and Strategy Use Task. Reading comprehension and strategy use was assessed using three stories taken from the Gray Oral Reading Test (GORT, Wiederholt \& Bryant, 2012). The three short stories that increased in difficulty and was followed by three reading comprehension questions (see Appendix C). Participants read each story and completed four think-aloud responses per story. After every second sentence, participants were cued to conduct their think-aloud by a beeping sound. Participants expressed their thought-processes about what they had just read. All participants were presented with a list of strategy cues in order to enhance their thinkaloud responses with the hopes of improving their reading comprehension success (see Appendix D). In a pilot study conducted with pre-service French teachers, strategy prompts produced more complex reading strategies in comparison to unprompted reading (Friesen \& Frid, in prep). The reading comprehension task commences with one recorded exemplar of a think-aloud for a sample story. Following each story, three reading comprehension questions were presented consecutively, and participants were required to respond to the questions aloud. The reading comprehension questions included one literal question, one question that required necessary inferencing and one question that required elaborative inferencing. This task was completed in English and in French. 


\subsection{Procedure}

Prior to the start of the study, ethics approval was obtained from the university's non-medical research ethics boards (Appendix E) and subsequently by the school board research committee. Recruiting emails were sent by the researchers to the principals of selected French Immersion schools within the school board describing the study and inviting them to volunteer their school for participation. Once principals agreed, the researcher delivered pre-made packages to the school. Guardians of each potential participant received a package, which included the letter of information, consent form and Parent/Guardian Questionnaire. Guardians completed the consent form and Questionnaire, inserted them back into the envelope and delivered them back to the school. Participants signed an assent form before commencing with the study.

Sessions. Each participant was asked to complete two testing sessions individually over a maximum period of one month. The students met with the researcher in a quiet space in the school during instructional periods for approximately 30 minutes per session. One session was conducted in English and the other session was in French. The order of the sessions were counterbalanced (i.e., English than French or vice versa). Within each session, all tasks were completed in the same order: PPVT, reading comprehension task, and TOWRE.

At the start of session one, the researcher explained the study to the participant and the concept of confidentiality and voluntary research participation. Students were told that the research was in no way related to their grades and studies at school, and they could stop participating at any point without consequences. Participants signed a letter of assent once they decided that they were interested in participating in the study. 
Students began by completing the PPVT and reading comprehension task on a laptop computer using the software e-Prime (Psychology Software Tools, Pittsburgh, PA). Participant reading comprehension responses and think-aloud responses were audio recorded for coding purposes. Participants then completed the TOWRE by reading a list of words and non-words off a laminated sheet. At the conclusion of testing, guardians of the participants were encouraged to contact the primary investigator with questions or comments regarding the study. Each school was given a data summary on the performance of their students and the preliminary findings at that point in time.

Think-Aloud Data Coding. Audio recordings of the reading comprehension task were analyzed and coded as strategies. For each think-aloud, students had approximately one minute to speak. There were four opportunities to conduct a think-aloud per story (i.e., 12 think-alouds). Think-aloud responses were coded according to pre-determined strategies (see Appendix F). The researcher listened to each think-aloud and tallied the number of times they used each of the identified strategies. In order to categorize the strategies into a more succinct analysis, strategies were grouped based on the three Construction-Integration levels. Surface form strategies included references to vocabulary, text or sentence structure. Textbase strategies included summarizing and necessary inferencing. Lastly, situation model strategies included predicting, elaborative inferencing, visualization, questioning and references to background knowledge. The process of grouping independent strategies into these 3 levels was completed with the purpose of understanding how these levels predict reading comprehension success through the lens of this specific theory. Reading comprehension responses were scored out of 2 ( 0 being incorrect, 1 being partially correct, 2 being completely correct). There 
were 3 questions per story with a potential maximum score of 18 . Think-aloud data and reading comprehension responses where the coding was unclear were listened to by other researchers in the lab in order to achieve consensus.

\section{Chapter 3}

\section{Results}

Four research questions were posed in this study. They included (1) what type of reading comprehension strategies do emergent bilingual children in French Immersion use when processing texts? (2) Do emergent bilingual children engage in similar reading strategies in both their first and second languages? (3) What role does vocabulary knowledge, reading fluency and strategy use play in successful reading comprehension? (4) If a reader uses a strategy in one language do they also use the strategy in their other language?

\subsection{Strategy Recruitment in L1 and L2}

When analyzing strategy use, type of strategy was as an independent variable with 10 levels (i.e. summarizing, predicting, necessary inferencing, questioning, etc.) and to simplify the analysis the 10 strategies were categorized into three strategy types based on the Construction-Integration model (i.e. surface form, textbase and situation model). Two repeated measures of analysis of variance (ANOVA) were conducted with language (English and French) and strategy type (either 10 levels or 3 levels) as the independent variables and number of instances as the dependent variable. The purpose of the ANOVA was to establish whether independent strategies differed between languages (see Table 1 
$\&$ Figure 1) and whether grouped strategies differed between languages (see Table $2 \&$ Figure 2).

In the analysis where all 10 strategies were included, there was a main effect of language, $F(1,69)=15.75, p<.001, \eta_{p}{ }^{2}=0.186$, a main effect of strategy, $F(9,621)=$ $27.71, p<.001, \eta_{p}{ }^{2}=0.287$, and an interaction between language and strategy, $F(9,621)=$ 25.71, $p<.001, \eta_{p}{ }^{2}=0.271$. In the second ANOVA, there was a main effect of language, $F(1,69)=15.75, p<.001, \eta_{p}{ }^{2}=0.186$, a main effect of strategy, $F(2,138)=59.96, p<$ $.001, \eta_{p}{ }^{2}=0.465$, and an interaction between language and strategy, $F(2,138)=63.78, p$ $<.001, \eta_{p}{ }^{2}=0.480$. A main effect of language means that differences in behavior between English and French were observed and a main effect of strategy means that differences exist between strategy use. A significant interaction between language and strategy means that individuals were using different strategies when reading in English versus French.

Table 1. Means and Standard Deviations of Number of Times Each Strategy was Employed in Each Language

\begin{tabular}{lcc}
\hline Type of Strategy & English & French \\
\hline Vocabulary & $0.01(0.1)$ & $2.16(3.6)$ \\
Text & $0.06(0.2)$ & $0.07(0.3)$ \\
Sentence Structure & $0.01(0.1)$ & $0.0(0.0)$ \\
Summarizing & $2.50(4.1)$ & $6.09(4.1)$ \\
Necessary Inferencing & $2.86(3.6)$ & $1.07(1.8)$ \\
Elaborative Inferencing & $3.11(3.5)$ & $1.11(1.7)$ \\
Predicting & $3.06(2.8)$ & $1.11(1.5)$
\end{tabular}



Questioning
$2.30(3.2)$
$1.03(1.5)$
Visualizing
$1.74(3.1)$
$0.26(0.6)$
Background Knowledge
$1.56(2.2)$
$0.77(1.3)$

\section{Table 2. Means and Standard Deviations of Each Group of Strategies in Each Language}

\begin{tabular}{ccc}
\hline Type of Strategy & English & French \\
\hline Surface Form Strategies & $0.09(0.3)$ & $2.23(3.6)$ \\
Textbase Strategies & $5.36(6.5)$ & $7.16(4.6)$ \\
Situation Model Strategies & $11.77(5.1)$ & $4.29(3.5)$ \\
\hline
\end{tabular}

Bonferroni post-hoc tests determined that for specific strategies, students were predicting more in English than French $(p<.001)$, making necessary inferences more in English than French $(p<.001)$, making elaborative inferences more in English than French $(p<.001)$, questioning more in English than French $(p=.003)$, visualizing more in English than French $(p<.001)$ and using background knowledge more in English than French $(p=.005)$. Students were identifying vocabulary words more in French than English $(p<.001)$ and summarizing more in French than English $(p<.001)$. Text and sentence structure did not differ significantly between languages (Figure 1a \& 1b).

Bonferroni post-hoc tests determined that for grouped strategies, students were using surface form strategies more often in French than English $(p<.001)$ and using 
textbase strategies more often in French than English ( $p=.011)$. Students used more situation model strategies in English than French $(p<.001)$ (Figure 2a \& 2b).

a)

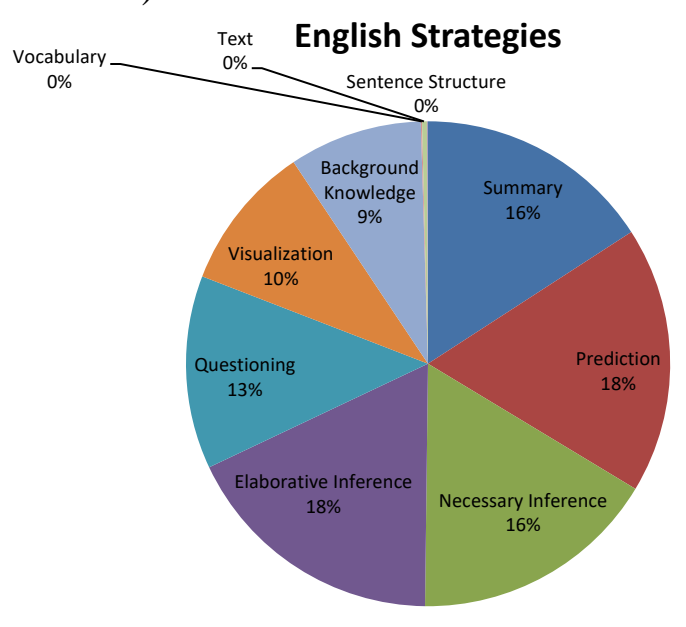

b)

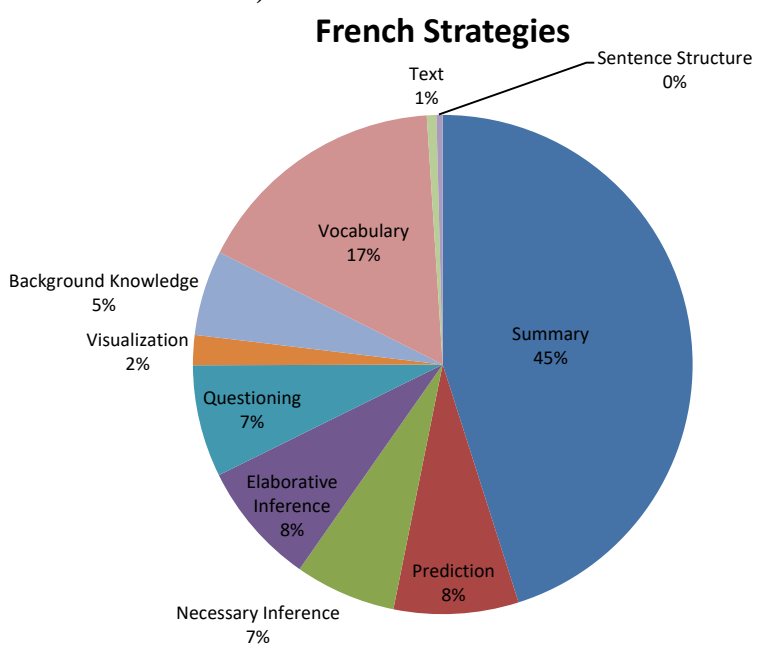

Figure 1. Proportion of each strategy type used in (a) English and (b) French thinkalouds.

a)

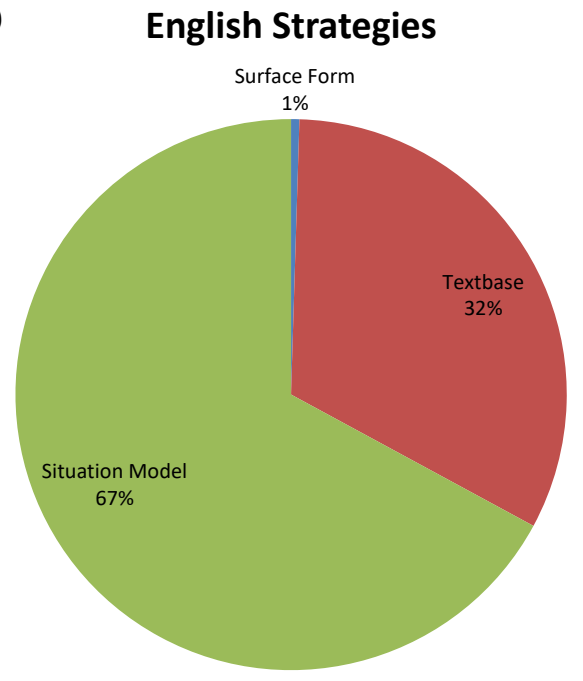

b) French Strategies

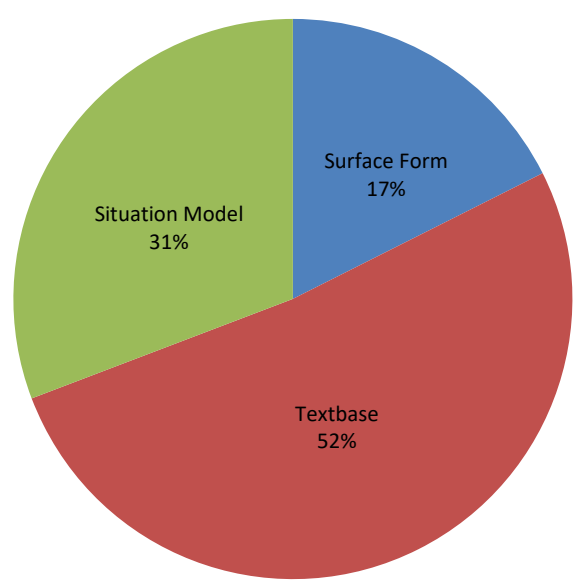

Figure 2. Proportion of each grouped strategy type used in (a) English and (b) French think-alouds. 


\subsection{Language Proficiency and Strategy Use as Predictors of Reading Comprehension Success}

The descriptive statistics for language proficiency measures and reading comprehension scores are reported in Table 3. Students achieved a higher score in the English reading comprehension than French reading comprehension, $t(69)=8.39, p$ $<.001$. They were more successful in the English word fluency measure than the French word fluency measure, $t(69)=12.95, p<.001$. Students did not significantly differ across languages in the non-word fluency measure, $t(69)=1.48$, n.s. Lastly, their English vocabulary knowledge exceeded their French vocabulary knowledge, $t(69)=13.65, p$ $<.001$.

Table 3. Means and Standard Deviations for Language Measures in both English and French (Values Marked with an * Significantly Differed between Languages)

\begin{tabular}{lcc}
\hline Language Measures & English & French \\
\hline Reading Comprehension Score & $* 9.83(2.8)$ & $* 6.04(3.9)$ \\
Word Fluency Score & $* 67.37(10.1)$ & $* 53.80(11.6)$ \\
Non-Word Fluency Score & $32.64(10.4)$ & $31.24(11.0)$ \\
Vocabulary Knowledge Score & $* 142.24(20.6)$ & $* 89.61(30.0)$ \\
\hline
\end{tabular}

Several stepwise multiple regression analyses were completed in order to determine whether vocabulary knowledge, word reading fluency and strategy recruitment predict reading comprehension success. Three regression analyses were conducted in each language on the Reading Comprehension score: 1) included same-language proficiency measures and individual strategies, 2) included same-language proficiency 
measures and grouped strategies, 3) included cross-language proficiency measures and strategy use in the other language.

The first regression model used English reading comprehension as the dependent measure. The English proficiency measures and the number of instances of use for each strategy served as the predictors. The multiple regression model with every significant English predictor produced $\mathrm{R}^{2}=0.396, F(5,69)=8.40, p<.001$. English vocabulary knowledge and English non-word fluency had significant positive regression weights, indicating students with higher scores on these measures were expected to have higher English reading comprehension scores, after controlling for the other variables in the model. English summarizing, English elaborative inferencing and English necessary inferencing also had significant positive regression weights, indicating students who engaged in these strategies were expected to have higher English reading comprehension scores (see Table 4).

Table 4. Coefficient Table of English Variables that Predict Successful English Reading Comprehension (Strategies are Analyzed Independently)

\begin{tabular}{lccccc}
\hline Predictors & B & SE & Beta & $\boldsymbol{t}$ & Sig. \\
\hline Constant & -0.88 & 2.08 & & -0.42 & $n . s$. \\
& & & & & \\
English PPVT & 0.04 & 0.01 & 0.31 & 3.15 & $=.002$ \\
& & & & & \\
English Summarizing & 0.16 & 0.07 & 0.23 & 2.14 & $=.036$ \\
& & & & & \\
English Non-Word Fluency & 0.09 & 0.03 & 0.33 & 3.21 & $=.002$
\end{tabular}


English Elaborative

Inferencing

English Necessary

Inferencing
$0.24 \quad 0.08$

0.23

0.09

0.30

2.75

3.00

$=.004$

0.30

\subsection{5}

$=.008$

The second regression model looked at English reading comprehension and English predictors, but the strategies analyzed were grouped. The multiple regression produced $\mathrm{R}^{2}=0.401, F(4,69)=10.88, p<.001$. English vocabulary knowledge and English non-word fluency had significant positive regression weights, indicating students with higher scores on these measures were expected to have higher English reading comprehension scores, after controlling for the other variables in the model. English textbase strategies and English situation model strategies had significant positive regression weights, indicating students who engaged in these strategies were expected to have higher English reading comprehension scores (see Table 5).

Table 5. Coefficient Table of English Variables that Predict Successful English Reading Comprehension (Strategies are Analyzed in Construction-Integration Model Groupings)

\begin{tabular}{lccccc}
\hline Predictors & B & SE & Beta & $t$ & Sig. \\
\hline Constant & -3.03 & 2.27 & & -1.33 & $=.187$ \\
& & & & & \\
English Textbase Strategies & 0.27 & 0.05 & 0.62 & 5.17 & $<.001$ \\
English PPVT & 0.05 & 0.01 & 0.34 & 3.49 & $=.001$ \\
$\begin{array}{l}\text { English Situation Model } \\
\text { Strategies }\end{array}$ & 0.20 & 0.06 & 0.37 & 3.14 & $=.003$
\end{tabular}


$\begin{array}{llllll}\text { English Non-Word Fluency } & 0.08 & 0.03 & 0.29 & 2.98 & =.004\end{array}$

In the third regression model of English reading comprehension, French predictors were included as predictor variables. Independent French strategies were added to the model. The multiple regression model with every significant French predictor produced $\mathrm{R}^{2}=0.151, F(2,69)=5.95, p=.004$. French word fluency had significant positive regression weights, indicating students with higher scores on this measure were expected to have higher French reading comprehension scores, after controlling for the other variables in the model. French elaborative inferencing had a significant positive regression weight, indicating students who engaged in this strategy were expected to have higher English reading comprehension scores (see Table 6).

Table 6. Coefficient Table of French Variables that Predict Successful English Reading Comprehension (Strategies are Analyzed Independently)

\begin{tabular}{lrrrrc}
\hline Predictors & B & SE & Beta & $t$ & Sig. \\
\hline Constant & 6.10 & 1.53 & & 3.99 & $<.001$ \\
French Elaborative Inferencing & 0.55 & 0.19 & 0.33 & 2.90 & $=.005$ \\
French Word Reading Fluency & 0.06 & 0.03 & 0.24 & 2.13 & $=.037$ \\
\hline
\end{tabular}

In the fourth regression model, French reading comprehension was the dependent measure. The French proficiency measures and the number of instances of use for each strategy served as the predictors. The multiple regression model with every French predictor produced $\mathrm{R}^{2}=0.580, F(7,69)=12.22, p<.001$. French vocabulary knowledge and French word fluency had significant positive regression weights, indicating students 
with higher scores on these measures were expected to have higher French reading comprehension scores, after controlling for the other variables in the model. French predicting, French elaborative inferencing, French questioning and French background knowledge had significant positive regression weights, indicating students who engaged in these strategies were expected to have higher French reading comprehension scores (see Table 7).

Table 7. Coefficient Table of French Variables that Predict Successful French Reading Comprehension (Strategies are Analyzed Independently)

\begin{tabular}{|c|c|c|c|c|c|}
\hline Predictors & $\overline{\mathbf{B}}$ & $\overline{\mathrm{SE}}$ & $\overline{\text { Beta }}$ & $\bar{t}$ & Sig. \\
\hline Constant & -8.39 & 1.87 & & -4.50 & $=.014$ \\
\hline $\begin{array}{l}\text { French Word } \\
\text { Reading } \\
\text { Fluency }\end{array}$ & 0.12 & 0.03 & 0.35 & 4.07 & $<.001$ \\
\hline $\begin{array}{l}\text { French } \\
\text { Predicting }\end{array}$ & 0.76 & 0.23 & 0.29 & 3.34 & $=.001$ \\
\hline French PPVT & 0.04 & 0.01 & 0.31 & 3.65 & $=.001$ \\
\hline $\begin{array}{l}\text { French } \\
\text { Background } \\
\text { Knowledge }\end{array}$ & 0.56 & 0.27 & 0.18 & 2.04 & $=.046$ \\
\hline $\begin{array}{l}\text { French } \\
\text { Elaborative } \\
\text { Inferencing }\end{array}$ & 0.66 & 0.20 & 0.28 & 3.25 & $=.002$ \\
\hline $\begin{array}{l}\text { French } \\
\text { Summarizing }\end{array}$ & 0.28 & 0.09 & 0.30 & 3.17 & $=.002$ \\
\hline $\begin{array}{l}\text { French } \\
\text { Questioning }\end{array}$ & 0.76 & 0.25 & 0.30 & 3.06 & $=.003$ \\
\hline
\end{tabular}

In the fifth regression model, French reading comprehension was analyzed, and French predictors were included, but the strategies analyzed were grouped. The multiple regression produced $\mathrm{R}^{2}=0.569, F(4,69)=21.45, p<.001$. French vocabulary 
knowledge and French word fluency had significant positive regression weights, indicating students with higher scores on these measures were expected to have higher French reading comprehension scores, after controlling for the other variables in the model. French situation model strategies and French textbase strategies had significant positive regression weights, indicating students who engaged in these strategies were expected to have higher French reading comprehension scores (see Table 8).

Table 8. Coefficient Table of French Variables that Predict Successful French Reading Comprehension (Strategies are Analyzed in Construction-Integration Model Groupings)

\begin{tabular}{|c|c|c|c|c|c|}
\hline Predictors & $\mathbf{B}$ & SE & Beta & $\bar{t}$ & Sig. \\
\hline Constant & -8.58 & 1.86 & & -4.62 & $<.001$ \\
\hline $\begin{array}{l}\text { French Situation Model } \\
\text { Strategies }\end{array}$ & 0.64 & 0.10 & 0.57 & 6.47 & $<.001$ \\
\hline $\begin{array}{l}\text { French Word Reading } \\
\text { Fluency }\end{array}$ & 0.12 & 0.03 & 0.37 & 4.43 & $<.001$ \\
\hline French PPVT & 0.04 & 0.01 & 0.31 & 3.71 & $<.001$ \\
\hline French Textbase Strategies & 0.22 & 0.08 & 0.26 & 2.98 & $=.004$ \\
\hline
\end{tabular}

In the final regression model, French reading comprehension was analyzed, and English predictors were included. Independent English strategies were added to the model. The multiple regression model with every French predictor produced $R^{2}=0.427$, $F(2,69)=24.98, p<.001$. English vocabulary knowledge and English non-word fluency had significant positive regression weights, indicating students with higher scores on 
these measures were expected to have higher French reading comprehension scores, after controlling for the other variables in the model (see Table 9).

Table 9. Coefficient Table of English Variables that Predict Successful French Reading Comprehension (Strategies are Analyzed Independently)

\begin{tabular}{lccccc}
\hline Predictors & B & SE & Beta & $t$ & Sig. \\
\hline Constant & -10.84 & 2.67 & & -4.06 & $<.001$ \\
$\begin{array}{l}\text { English Non-Word Reading } \\
\begin{array}{l}\text { Fluency } \\
\text { English PPVT }\end{array}\end{array}$ & 0.17 & 0.04 & 0.46 & 4.96 & $<.001$ \\
& 0.08 & 0.02 & 0.41 & 4.45 & $<.001$ \\
\hline
\end{tabular}

To visualize the strength of regression equations 1 and 4, the predicted reading comprehension values were calculated. This was done with the data for English reading comprehension when English language proficiency measures and the significant independent English strategies were included in the model (see Figure 3). This was done with the data for French reading comprehension when French language proficiency measures and the significant independent French strategies were added to the model (see Figure 4). 


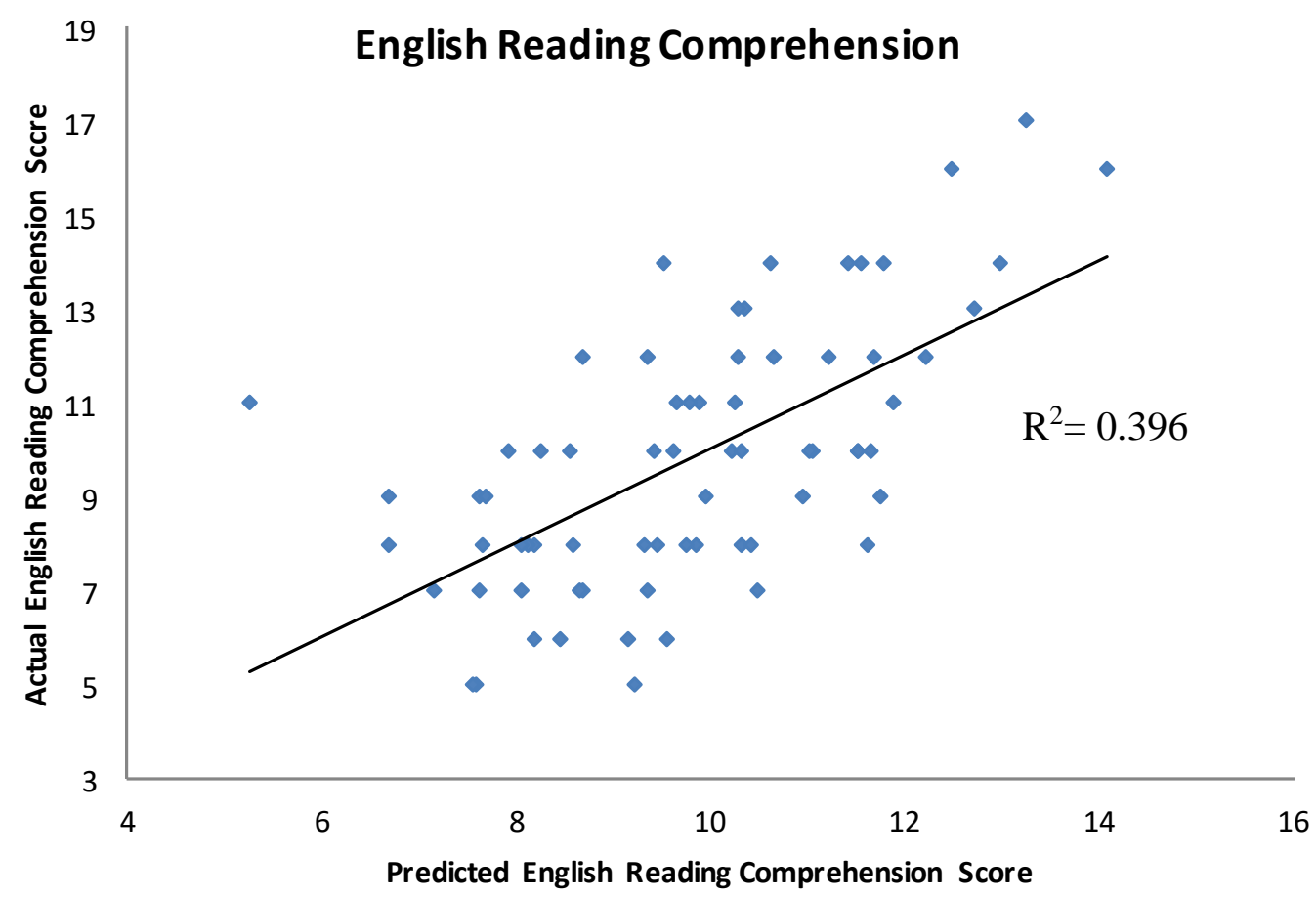

Figure 3. This figure shows that English RC performance can be predicted using a linear equation from a combination of scores on several predictive measures. English Reading Comprehension $=\mathbf{- 0 . 8 7 5}+0.042($ vocabulary knowledge $)+0.088$ (word fluency) $+0.156($ summarizing $)+0.234$ (necessary inferencing $)+0.243$ (elaborative inferencing) 


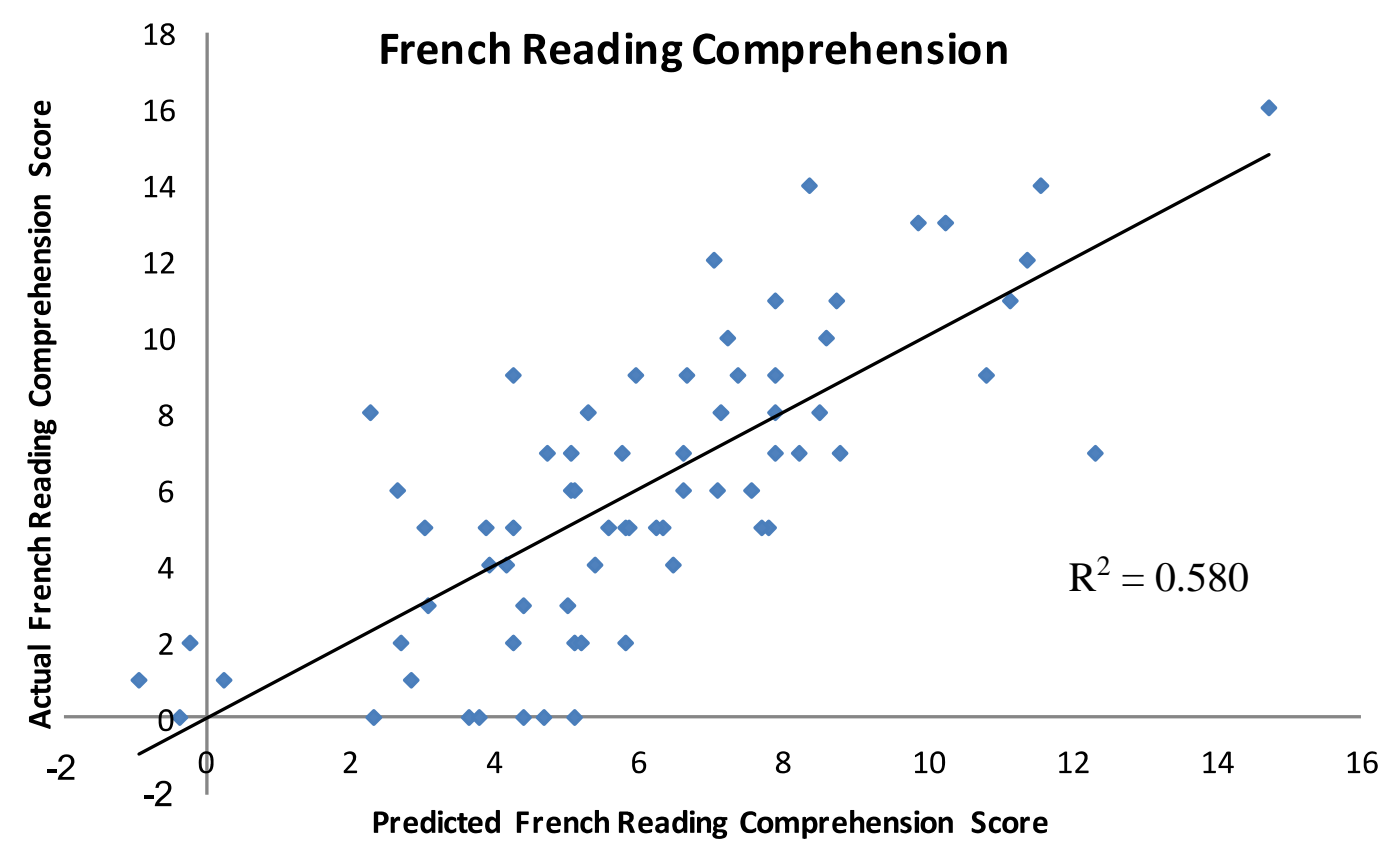

Figure 4. This figure shows that French $\mathrm{RC}$ performance can be predicted using a linear equation from a combination of scores on several predictive measures. French Reading Comprehension $=-\mathbf{8 . 3 9 1}+0.04($ vocabulary knowledge $)+0.117$ (word fluency) +0.284 (summarizing) +0.761 (predicting) +0.661 (elaborative inferencing) +0.759 (questioning) + 0.557 (background knowledge)

\subsection{Cross-Language Strategy Predictors}

Bivariate correlations were calculated to determine whether strategies used in English reading were also recruited in French (see Table 10). Figure 5 has the English strategies that were observed to predict English reading comprehension. Figure 6 has the French strategies that were observed to predict French reading comprehension 
Table 10. Correlations between Each Individual Strategy between English and French (Values Marked with an * Significantly Differed between Languages)

\begin{tabular}{cc}
\hline Type or Strategy & Correlation \\
Vocabulary & -0.005 \\
Text & -0.057 \\
Sentence Structure & 0 \\
Summarizing & $0.463 * *$ \\
Necessary Inferencing & 0.221 \\
Elaborative Inferencing & 0.201 \\
Predicting & $0.288^{*}$ \\
Questioning & 0.072 \\
Visualizing & $0.279 *$ \\
Background Knowledge & $0.239 *$ \\
\hline
\end{tabular}




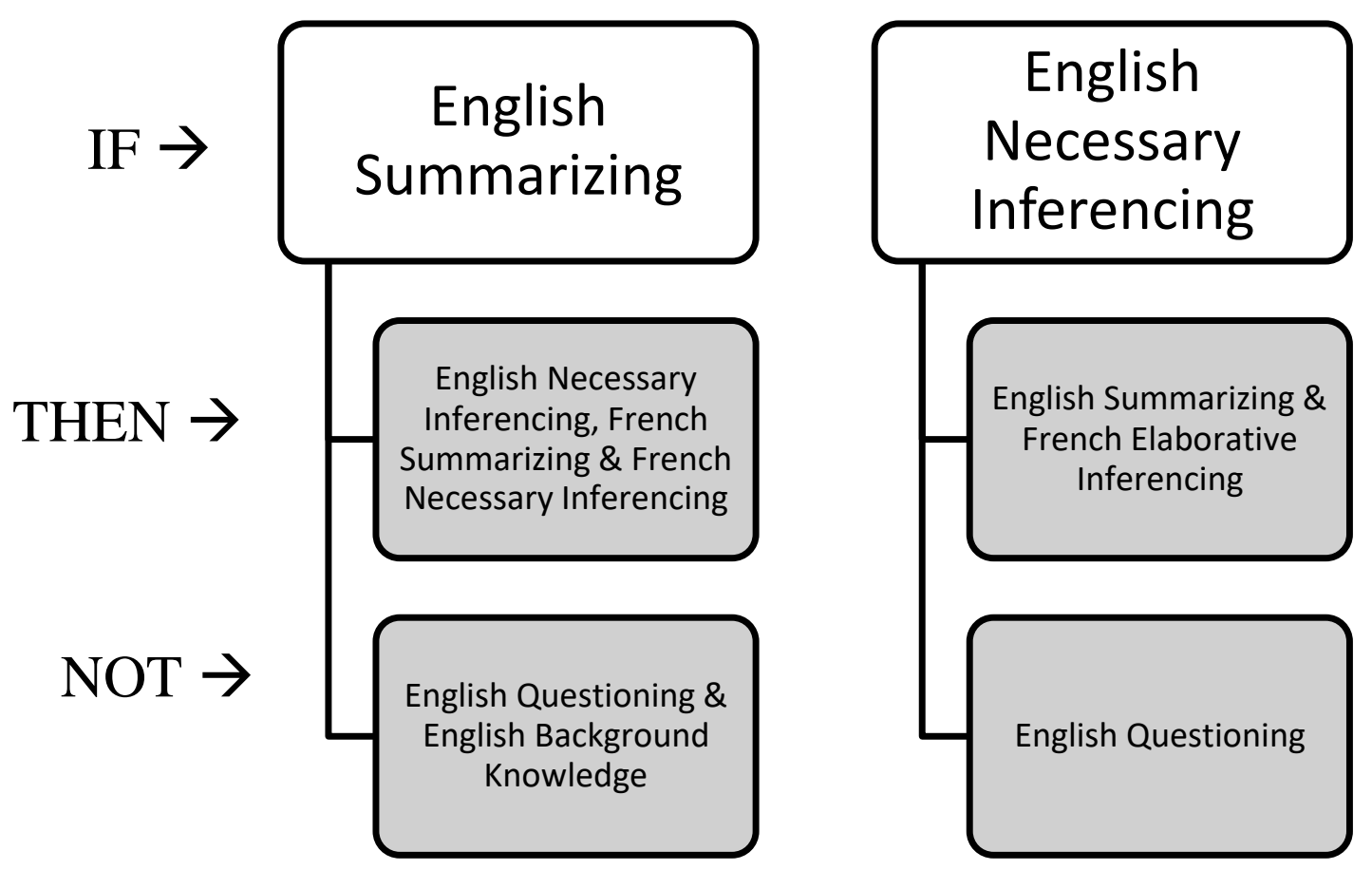

Figure 5. The uppermost box has an English strategy that predicts English reading comprehension success. The second box down contains the English and French strategies that are also recruited when the strategy in the first box is recruited. The third box down contains the English and French strategies that are not recruited when the strategy in the first box is recruited 

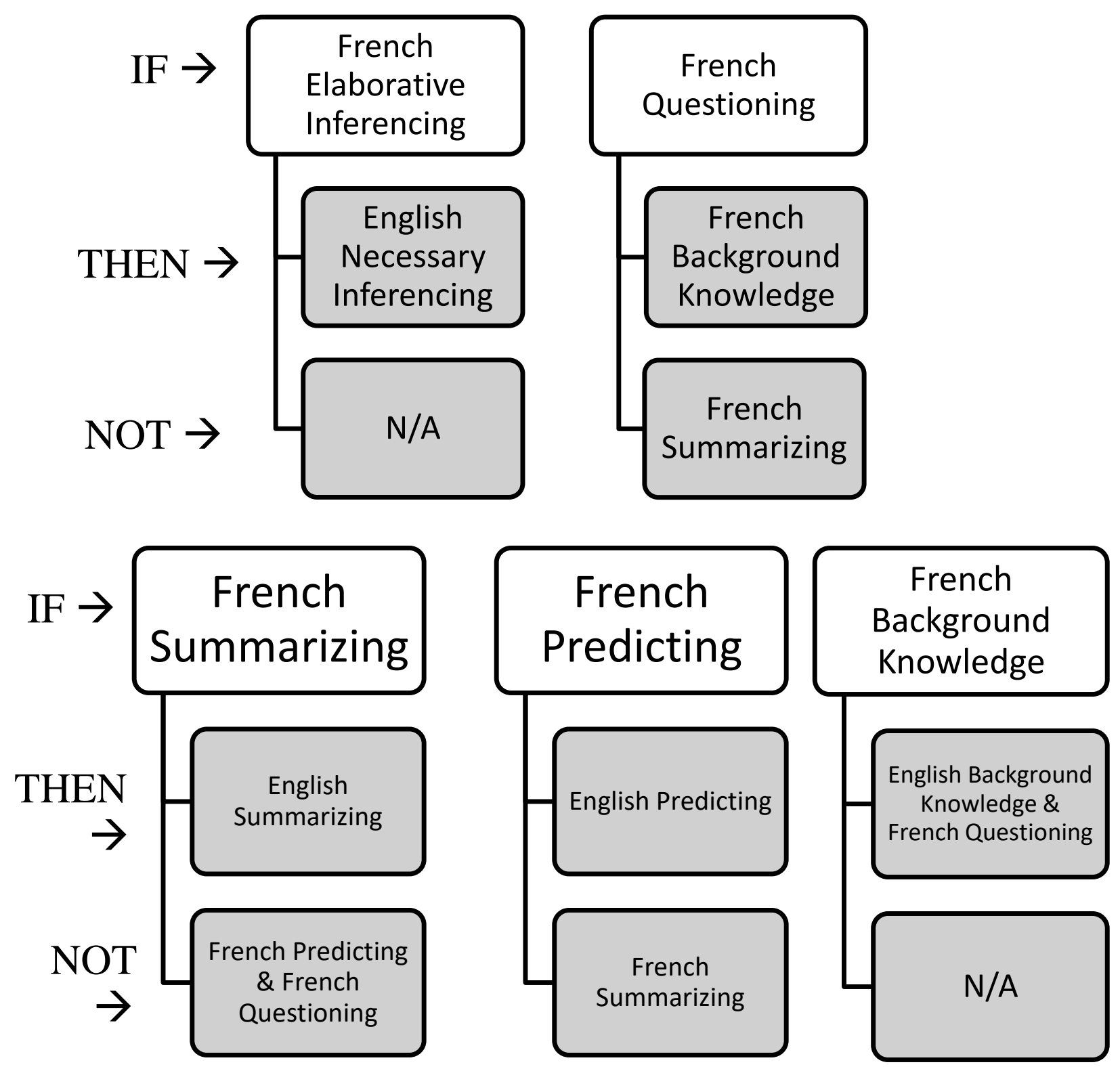

Figure 6. The uppermost box has a French strategy that predicts French reading comprehension success. The second box down contains the French and English strategies that are also recruited when the strategy in the first box is recruited. The third box down contains the French and English strategies that are not recruited when the strategy in the first box is recruited 


\section{Chapter 4}

\section{Discussion}

The goal of the current research was to determine whether reading strategy recruitment and language proficiency measures (i.e., vocabulary knowledge and reading fluency) could predict successful English and French reading comprehension amongst fourth- and fifth-grade French immersion students. A think-aloud reading comprehension task, a vocabulary measure and a reading fluency measure were administered in each language. Students recruited different strategies in their L1 and L2. Specifically, situation model strategies (i.e., predicting, elaborative inferencing, and background knowledge) were used more often in English than French and textbase strategies (i.e., summarizing) were used more often in French than English. English textbase and situation model strategies predicted successful English reading comprehension and, French textbase and situation model strategies predicted successful French reading comprehension. These strategies each accounted for unique variance in reading comprehension performance. Relying on these strategies allows readers to understand the text and consolidate it into memory.

For cross-language predictors, French elaborative inferencing and French word reading predicted English reading comprehension and English non-word reading and English vocabulary knowledge predicted French reading comprehension. Although crosslanguage predictors produced significant regression models, they accounted for less variance than within language models. Cross-language strategy recruitment shows that many of strategies that are recruited in English are also recruited in French, although the correlations are small. 


\subsection{Interpretation of Results}

Language proficiency differed between English and French. The French immersion students in the sample obtained higher reading comprehension scores, vocabulary knowledge scores and word reading scores in English. Although, these students are only receiving English instruction in fourth-grade, the majority of the participants in the study had English as their first language. Furthermore, they were receiving English input at home prior to fourth-grade. The students' parents reported that their children spent more time reading in English than in French. This result is consistent with Roy and Galiev (2011) who report that students in French immersion programs in Canada are more proficient in English than in French.

4.1.1 Strategy recruitment in L1 and L2. Different strategies were recruited when reading in English than French. When reading in English, students were using significantly less summarizing and were not recruiting vocabulary identification at all. However, visualizing, predicting and referring to background knowledge was recruited significantly more in English than French. Using less summarizing while reading in English and neglecting to comment on English vocabulary may be due to English being a first language and the participants' confidence in understanding the English texts. Students may not be fully understanding the English texts; however, they are more confident in their interpretation of the passages since English was their L1. Visualizing, predicting and background knowledge were categorized as situation model strategies. These strategies enable the reader to consolidate the text to memory by integrating background knowledge with the textbase (Kintsch, 1988). Malicky, Fagan and Norman 
(1988) also found that French immersion students are better able to integrate previous background knowledge to their English reading in comparison to their French reading. In order to confirm understanding of a text, paraphrasing or summarizing tend to be utilized. When reading in French, students were summarizing the most and commenting on French vocabulary words that were unfamiliar to them. This is likely due to French being a second, less-proficient language in comparison to English. Jimenez et al. (1996) determined that text-initiated strategies (i.e., vocabulary identification) are recruited more often when reading in one's less-proficient language in order to try and better understand what is being read. Furthermore, more complex strategy recruitment is used in more proficient languages since the reader understands the surface form of the text and can think about the text in a more sophisticated manner (i.e., connecting background knowledge or picturing what is happening in the story).

\subsubsection{Language proficiency and strategy use as predictors of reading}

comprehension success. Three key findings were observed from the multiple regression analyses on predictors of reading comprehension. The first finding is that although language knowledge (i.e., vocabulary knowledge and reading fluency) explains some success with reading comprehension, in both English and French, reading strategies also support success, independently of language proficiency. According to the Simple View of Reading (Gough \& Tunmer, 1986), reading ability is comprised of decoding and language/listening comprehension. This theory does not take into consideration the mental processes individuals undergo when reading a text. These results are consistent with the Construction-Integration model (Kintsch, 1988, 2005) that focuses on the levels of mental processing that result in text comprehension. This study provides support for 
Kintsch's model by demonstrating that strategy recruitment is a predictor of reading comprehension success in both L1 and L2.

The second key finding is that vocabulary knowledge and reading fluency were shown to be within language predictors for English and French reading comprehension. This supports previous research that has shown a link between language proficiency and comprehension (Grant, Gottardo \& Geva, 2012; Lipka \& Siegel, 2012). Lawrence, Hagen, Hwang, Lin and Lervag (2018) discuss the aptitude hypothesis as a theory to explain the relationship between vocabulary knowledge and reading comprehension. This hypothesis states that general aptitude may be the underlying factor that explains the correlation between high vocabulary knowledge and successful comprehension success. In other words, students who are stronger learners will be familiar with more word meanings and comprehend texts better (Stahl, 1983). Furthermore, vocabulary ability is often used as a proxy for overall language knowledge and it is this language knowledge that supports comprehension. Nagy (2007) referenced this hypothesis as an explanation for individual differences in vocabulary knowledge. Bialystok, Luk, Peet and Yang (2010) determined that less-proficient L2 knowledge makes it more difficult to acquire vocabulary knowledge in that language, which makes it more difficult to identify meaning when decoding words (i.e., reading fluency).

Despite the fact that vocabulary knowledge predicts unique variance in comprehension performance, students failed to comment on vocabulary during the English reading task. It is unclear whether they understood all the words or had trouble with some of the vocabulary but neglected to discuss that in their think-alouds. An interesting finding is that English non-word reading fluency predicted English reading 
comprehension and French word fluency predicted French reading comprehension. English is an inconsistent language, which makes non-word decoding more challenging in English than French. Indeed, it was the only behavioural measure where students performed equally in English and French. However, this likely means that non-word reading fluency has more variance and has a better chance of being a predictor of English comprehension than the word reading fluency measure.

The third key finding was that when grouped strategies were analyzed, textbase and situation model strategies in English and French were both significant predictors of comprehension success. This relates to Kintsch's model because the more complex levels of comprehension (textbase and situation model strategies) must be used in order to fully understand a text. In order to construct an understanding of a text, textbase strategies (i.e., summarizing and necessary inferencing) must be recruited. These strategies are important for comprehension since they allow the reader to paraphrase what they read to make sure they understand the meaning of the text. In order to reflect on the text past the textbase level, situation model strategies (i.e., visualizing, predicting, background knowledge, etc.) must be recruited. These strategies are important for comprehension because they allow the reader to engage with the text on a deeper level and use their past experiences of other readings/worldly events to integrate the meaning with their background knowledge in memory. Although students were recruiting fewer textbase strategies in English, summarizing and necessary inferencing in English predicted successful English reading comprehension. This may be due to the fact that engaging in these behaviours creates a text-base, which combines the reader's linguistic input and the text itself, which results in a better-quality representation of the text. Conversely, students who recruited more 
elaborative strategies during their French reading (i.e., predicting, elaborative inferencing, questioning and connecting background knowledge) had more successful French reading comprehension. Engaging in these behaviours accounts for the integration phase of the Construction-Integration Model (Kintsch, 1988). Students who were able to recruit these strategies, had a better text-based understanding and were able to incorporate their previous knowledge to aid in their understanding of the text.

4.1.3 Cross-language correlations in strategy use. Based on the above findings, it is clear that strategies that confirm understanding (e.g., summarizing) and strategies that consolidate text in memory (connecting to background information) are both important for reading comprehension success. Observing individual reading strategy use in one language can be informative about the type of reading strategies one can expect the reader to use in the other language. For instance, students who were summarizing in English were also summarizing in French and vice versa. This rang true for inferencing, predicting and connecting background knowledge as well. Students who are choosing to use the same strategies in both languages result in participants choosing strategies for familiarity and not in a responsive way to text difficulty. When looking at strategy recruitment between languages, correlations are small. Cummins (1991) language interdependence hypothesis can be used to explain the findings here. The model explains how higher order cognitive processes (i.e., strategy recruitment) are common across languages and may be recruited for both languages.

The results demonstrate that during the reading comprehension task, students tended to choose one type of strategy over the others rather than use a variety of strategies. When participants recruited textbase strategies in English, they did not recruit 
situation model strategies in English and vice versa. The same was shown with French strategies. For instance, when English summarizing was recruited, English questioning and English background knowledge were not and when French summarizing was recruited, French predicting, and French questioning were not. Furthermore, using textbase strategies and situation model strategies were both shown to be significant predictors of comprehension, yet students are choosing to do one or the other. One explanation for this may be because students who are commenting on the text itself may not be able to think deeply about the text and recruit situation model strategies and students who are able to consolidate the text to memory and recruit situation model strategies did not feel the need to use textbase strategies and comment on the semantics of the text. Although, both types of strategies are important separately, recruiting both strategies together while reading has been shown to be the best predictor of reading comprehension. Appropriate and diverse strategy selection should be practiced while reading to produce full comprehension.

Cross-language regression models of reading comprehension accounted for less variance than the within-language models. For instance, French elaborative inferencing predicts English reading comprehension success. Even though there were some significant cross-language predictors, specifically language proficiency measures, it is crucial to note that within-language predictors are better indicators of comprehension success.

\subsection{Implications for French Immersion Educators}

Strategy selection is a crucial component of reading comprehension. Once individuals are comfortable with the semantics of a text, they may engage in more 
complex strategies to think about the text more deeply. This may be the reason as to why surface form strategies (i.e., vocabulary identification, text analysis and sentence structure) were not recruited at all when reading in English. However, Meyer and Freedle (1984) determined that acknowledging text structure while reading contributes to reading comprehension success. Even though, these strategies were not recruited in English, does not mean they are not important to use when reading. It is beneficial to note that students in this study could improve on their English reading comprehension, even though their comprehension scores exceeded their French comprehension scores. Students who are only engaging in the meaning of the text and recruiting textbase strategies should be encouraged to make connection to their background knowledge to consolidate the information being read. Having students review their understanding of the text's important concepts before engaging in elaborative strategies would likely improve comprehension success amongst French immersion students.

Using a variety of textbase and situation model strategies could improve reading comprehension. French immersion teachers may want to focus on some of these strategies while scaffolding students during reading tasks in order to make sure they are comprehending the text. For instance, when teachers and students complete one-on-one readings, teachers can prompt their students to complete think-alouds (i.e., what do you think this story will be about? What can you picture in your head while reading this section?). Past studies have focused on the benefits of scaffolding during reading instruction and the idea that this method is a productive step in students becoming independent readers (Hobsbaum, Peters \& Sylva, 1996; Reynolds \& Daniel, 2017). In general, reading comprehension scores were not very high, despite student confidence. It 
is important to note the difference between reading to remember information (i.e., building a situation model) and reading to understand.

Strategies that were not recruited as frequently in either language include visualizing and questioning. Johnson-Laird (1983) believed that the most important aspect of reading was creating a mental model. Past research has observed that visualization results in reading comprehension gains (Erfani, Abutaleb \& Hossein, 2011; McNamara, 2007; Pressley, 2000). In terms of questioning, Yopp (1988) determined that questioning a text leads to improved comprehension. Specifically, students who generated their own questions about a text tended to have better comprehension. If students visualized or questioned more often, reading comprehension scores may have increased. Students were not gravitating towards these strategies on their own so teachers are encouraged to focus on these situation model strategies in their reading comprehension lessons.

Duke and Pearson (2002) discuss successful methods of reading comprehension instruction. They define five components: (1) description of strategy and how it should be used, (2) teacher/student modeling of the strategy, (3) collaborative use of strategy, (4) guided practice using the strategy, and (5) independent use of the strategy. Following this model in the classroom could help students learn the importance of each strategy and the appropriate time to use each strategy. Friesen and Haigh (2018) highlight several teaching approaches, besides the think-aloud, to assess strategies that students are currently using. They believe it is important for teachers to assess what strategies students are using while reading and if they are using them appropriately before deciding what strategies to teach them. The first technique is an interactive read-aloud, where the teacher chooses a 
particular book and models strategy use while reading with the student. Secondly, concept mapping involves creating a visual model of the connections students should make while they read. Finally, a reciprocal teaching approach involves engaging in a dialogue between the student and teacher about when and how strategies should be used.

\subsection{Limitations and Future Directions}

There are some limitations of this current study to consider. Firstly, every student was prompted with a sheet containing sentence starters during the think-aloud task. Each sentence starter resembled a potential strategy. For instance, "I predict that..." resembled a prediction and "I wonder if..." resembled a question. The decision to use prompts was made to ensure the participants knew how to complete the task. Presenting students with a list of prompts may result in them using strategies that they typically would not think to use. Veenman (2011) states the downside of prompting, which is the elimination of participant-initiated strategy recruitment. Therefore, providing prompts may discourage participants from choosing specific strategies and influence them to pick strategies that appear higher on the prompt sheet. That being said, questioning and visualizing were on the prompt sheet and under-represented in the data. The next step in this area of research is to compare prompted sessions with non-prompted sessions in order to determine if differences exist between prompting strategies and voluntary strategy expression. In a study by Friesen and Frid (in prep), they compared prompted vs. unprompted think-aloud tasks with adult participants and found that prompting resulted in more diverse strategy selection in participants' second language. This should be done with a student population to determine whether students who are prompted use more elaborative strategies than students who are unprompted. 
Next, the think-aloud protocol itself is an artificial method of assessing strategy recruitment. The fact that they have to verbalize what they are thinking as they read may not be the most reliable method of analyzing strategy use, despite the fact that it is a popularly-used paradigm (Coiro \& Dobler, 2007; Myers \& Lytle, 1986; Seipel, Carlson \& Clinton, 2017). Another method of investigating mental processes could be the use of eye tracking. One future study could have students complete the same task while their eyemovements are tracked. Eye tracking data could be coded to determine where students are spending more time fixating. For instance, if students are looking at a specific word more intently than this could mean they are having difficulty understanding the word. During their think-aloud it would be interesting to determine whether they mention that word at all. Furthermore, using an eye-tracking method could give more information on the mental processes being done by attending to the non-verbal behaviour participants are engaging in during the reading comprehension task.

Third, the stories for the think-aloud task were chosen with grade and age-level appropriateness in mind. However, it remains unclear whether the stories completely pair in terms of difficulty level. In other words, does the English easy-level story pair well to the French easy-level story and so on. This is a difficult limitation to address given that levelling texts is a function of the text itself but also the readers' characteristics (Diwersey, Everet \& Neumann, 2014). A pilot study could have been done prior to the start of the experiment to determine the appropriateness of each story. Fourth- and fifthgrade students could have read several stories and ranked them on a scale from 1 to 3 (i.e., 1 being easy, 2 being medium and 3 being hard). This could be done in the future if a similar methodology were to be used. 
Lastly, the students in this population were fourth- and fifth-grade French immersion students. In immersion programs, English instruction is only introduced in fourth-grade. It would be interesting to complete this study with older students, perhaps in grades six to eight, since they would have spent a few more years having English instruction. The findings in that cohort could inform researchers on the strategies upperyear French immersion students use while reading.

\subsection{Concluding Remarks}

Language proficiency (i.e., vocabulary knowledge and reading fluency) predicted reading comprehension, which supports the Simple View of Reading model (Gough \& Tunmer, 1986). However, strategy recruitment was also a significant predictor of reading comprehension. This supports the Construction-Integration model (Kintsch, 1988). The purpose of the current study was to expand on past research, which looked at how reading comprehension success differs between one's L1 and L2 and investigate the mental processes that influence reading comprehension differences between languages. Reading in English versus French resulted in differing strategy use, which could be due to the individual's proficiency in each language. More proficient language knowledge results in more complex strategy use while less proficient language knowledge resulted in more text-based strategies. The findings of this current study give a new lens to the research being conducted with French immersion students and the manner in which they process texts in their L1 and L2. The knowledge gained from this research could inform educators in the immersion system of the strategies to engage their students with and the manner in which to do so. 


\section{References}

Afflerbach, P., Pearson, P. D., \& Paris, S. G. (2008). Clarifying differences between reading skills and reading strategies. The Reading Teacher, 61(5), 364-373.

Au-Yeung, K., Hipfner-Boucher, K., Chen, X., Pasquarella, A., D’Angelo, N., \& Deacon, H. (2014). Development of English and French language and literacy skills in EL1 and EL French immersion students in the early grades. Reading Research Quarterly, 50(2), 233-254.

Babbs, P. J. (1984). Monitoring cards help improve comprehension. The Reading Teacher, 38(2), 200-204.

Baier, R. J. (2005). Reading comprehension and reading strategies. Published Dissertation. Master of Education Degree in Education. The Graduate School: University of Wisconsin-Stout.

Baker, C. (2011). Foundations of bilingual education and bilingualism. Multilingual Matters, 79.

Bialystok, E., Luk, G., Peets, K.F., \& Yang, S. (2010). Receptive vocabulary differences in monolingual and bilingual children. Bilingualism, Language and Cognition, 13, $525-531$.

Bialystok, E., Peets, K. F., \& Moreno, S. (2011). Producing bilinguals through immersion education: Development of metalinguistic awareness. Applied Psycholinguistics, $35,177-191$.

Blachowicz, C., \& Ogle, D. (2017). Reading comprehension: Strategies for independent learners. Guilford Publications. 
Bournot-Trites, M., \& Tellowitz, U. (2002). Report of current research on the effects of second language learning on first language literacy skills. Printing House.

Bowen, C. J., \& Howie, P. M. (2002). Context and cue cards in young children's testimony A comparison of brief narrative elaboration and context reinstatement. Journal of Applied Psychology, 87(6), 1077-1085.

Britton, B. K., \& Graesser, A. C. (2014). Extending Capacity-Constrained Construction Integration: Toward "Smarter" and Flexible Models of Text Comprehension. In Models of Understanding Text (pp. 81-122). Psychology Press.

Burstall, C. (1975). Primary French in the balance. Educational Research, 17, 193-198. Canadian Parents for French. (2008). French Second Language Education in Ontario. Report and Recommendations to the Ontario Minister of Education, Mississauga, ON.

Chu, J. (2016). Examining Students' Strategies for Promoting Word Knowledge and Reading Competence in French Immersion Students. Journal of Classroom Research in Literacy, 9, 20-30.

Chung, S. C., Koh, P. W., Deacon, H., \& Chen, X. (2017). Learning to read in English and French: Emergent readers in French immersion. Top Language Disorders, 37(2), 136-153.

Coiro, J., \& Dobler, E. (2007). Exploring the online reading comprehension strategies used by sixth-grade skilled readers to search for and locate information on the Internet. Reading research quarterly, 42(2), 214-257. 
Comeau, L., Cormier, P., Grandmaison, É., \& Lacroix, D. (1999). A longitudinal study of phonological processing skills in children learning to read in a second language. Journal of Educational Psychology, 91(1), 29.

Cummins, J. (1991). Interdependence of first- and second-language proficiency in bilingual children. In E. Bialystok (Ed.), Language processing in bilingual children; language processing in bilingual children (pp. 70-89, Chapter xiii, 238 Pages) Cambridge University Press, New York, NY.

Cummins, J. (1998). Immersion education for the millennium: What have we learned from 30 years of research on second language immersion? In M. R. Childs \& R. M. Bostwick (Eds.) Learning through two languages: Research and practice. Second Katoh Gakuen International Symposium on Immersion and Bilingual Education. (pp.34-47). Katoh Gakuen, Japan.

Cummin, J. (2014). To what extent are Canadian second language policies evidencebased? Reflections on the intersections of research and policy. Frontiers in Psychology, 5(358), 1-10.

Deacon, S. H., Wade-Woolley, L., \& Kirby, J. (2007). Crossover: The role of morphological awareness in French immersion children's reading. Developmental Psychology, 43, 732-746.

Diwersy, S., Evert, S., \& Neumann, S. (2014). A weakly supervised multivariate approach to the study of language variation.” In B. Szmrecsanyi \& B. Wälchli (eds.), Aggregating dialectology, typology, and register analysis. Linguistic variation in text and speech, 174-204. Berlin/New York: Mouton de Gruyter. 
Duke, N. K., \& Pearson, P. D. (2009). Effective practices for developing reading comprehension. Journal of education, 189(1-2), 107-122.

Dunn, L. M., \& Dunn, L. M. (1997). Examiner's manual for the PPVT-III peabody picture vocabulary test: Form IIIA and Form IIIB. AGS.

Erdos, C., Genesee, F., Savage, R., \& Haigh, C. (2014). Predicting risk for oral and written language learning difficulties in students educated in a second language. Applied Psycholinguistics, 35(2), 371-398.

Erfani, S. M., Iranmehr, A., \& Davari, H. (2011). Deepening ESP reading comprehension through visualization. Journal of Language Teaching and Research, 2(1), 270273.

Fitzgerald, J., \& Spiegel, D. (1983). Enhancing children's reading comprehension through instruction in narrative structure. Journal of Reading Behaviour, 15, 1-17.

Friesen, D. C., \& Haigh, C. A. (2018). How and why strategy instruction can improve second language reading comprehension: A review. The Reading Matrix: An International Online Journal, 18(1), 1-18.

García, O., \& Kleifgen, J. A. (2010). Educating emergent bilinguals: Policies, programs, and practices for English language learners. Teachers College Press.

Genesee, F. (1984). Beyond bilingualism: social psychological studies of French immersion programs in Canada. Canadian Journal of Behavioural Science/Revue Canadienne des Sciences du Comportement, 16(4), 338.

Genesee, F. (2004). What do we know about bilingual education for majority language students. Handbook of bilingualism and multiculturalism, 547, 576. 
Genesee, F., \& Jared, D. (2008). Literacy development in early French immersion programs. Canadian Psychology, 49(2), 140-147.

Geva, E., \& Clifton, S. (1994). The development of first and second language reading skills in early French immersion. The Canadian Modern Language Review, 50, 646-667.

Gough, P. B., \& Tunmer, W. E. (1986). Decoding, reading, and reading disability. RASE, 7(1), 6-10.

Grant, A., Gottardo, A., \& Geva, E. (2012). Measures of reading comprehension: do they measure different skills for children learning English as a second language? Reading and Writing, 25(8), 1899-1928.

Grinder, R., Otomo, A., \& Toyota, W. (1962). Comparisons between second, third, and fourth grade children in the audio-lingual learning of Japanese as a second language. The Journal of Educational Research, 56(4), 463-469.

Harlaar, N., Dale, P. S., \& Plomin, R. (2007). Reading exposure: A (largely) environmental risk factor with environmentally-mediated effects on reading performance in primary school years. Journal of Child Psychology and Psychiatry, 48(12), 1192-1199.

Hobsbaum, A., Peters, S., \& Sylva, K. (1996). Scaffolding in reading recovery. Oxford Review of Education, 22(1), 17-35.

Hoover, W. A., \& Gough, P. B. (1990). The simple view of reading. Reading and writing, 2(2), 127-160. 
Jared, D., Cormier, P., Levy, B.A., \& Wade-Woolley, L. (2011). Early predictors of biliteracy development in children in French immersion: A 4-year longitudinal study. Journal of Educational Psychology, 103(1), 119-139.

Jenkins, J. R., Fuchs, L. S., van den Broek, P., Espin, C., \& Deno, S. L. (2003). Sources of individual differences in reading comprehension and reading fluency. Journal of Educational Psychology, 95(4), 719-729.

Jimenez, R. T., Garcia, G. E., \& Pearson, P. D. (1996). The reading strategies of bilingual Latina/o students who are successful English readers: Opportunities and obstacles. Reading Research Quarterly, 31(1), 90-112.

Johnson-Laird, P. (1983). Mental Models. Cambridge, Mass.: Harvard University Press.

Karsenti, T., Collin, S., Villeneuve, S., Dumouchel, G., \& Roy, N. (2008). Why are new French immersion and French as a second language teachers leaving the profession? Results of a Canada-wide survey. Ottawa: Canadian Association of Immersion Teachers.

Kim, J. S., \& White, T. G. (2008). Scaffolding voluntary summer reading for children in grades 3 to 5: An experimental study. Scientific Studies of Reading, 12(1), 1-23.

Kintsch, W. (1988). The role of knowledge in discourse comprehension: A constructionintegration model. Psychological Review, 95(2), 163-182.

Kintsch, W. (2005). An overview of top-down and bottom-up effects in comprehension: The CI perspective. Discourse processes, 39(2-3), 125-128.

Kintsch, W., \& Welsch, D. M. (1991). The construction-integration model: A framework for studying memory for text. In W. E. Hockley \& S. Lewandowsky 
(Eds.), Relating theory and data: Essays on human memory in honor of Bennet B. Murdock (pp. 367-385). Hillsdale, NJ, US: Lawrence Erlbaum Associates, Inc. Lawrence, J. F., Hagen, A. M., Hwang, J. K., Lin, G., \& Lervag, A. (2018). Academic vocabulary and reading comprehension: Exploring the relationships across measures of vocabulary knowledge. Reading and Writing, 1-22.

Lervag, A., \& Aukrust, V. G. (2010). Vocabulary knowledge is a critical determination of the difference in reading comprehension growth between first and second language learners. Journal of Child Psychology and Psychiatry, 51, 612-620.

Lipka, O., \& Siegel, L. S. (2012). The development of reading comprehension skills in children learning English as a second language. Reading and Writing, 25, 18731898.

Lyster, R. (2004). Research on form-focused instruction in immersion classrooms: Implications for theory and practice. French Language Studies, 14, 321-341.

Lytle, S. (1982). Exploring comprehension style: A study of twelfth-grade readers' transactions with text. Unpublished doctoral dissertation, University of Pennsylvania.

Malicky, G. V., Fagan, W. T., \& Norman, C. A. (1988). Reading processes of French Immersion children reading in French and English. Canadian Journal of Education, 13, 277-289.

McDonald, J. L., \& Heilenman, L. K. (1992). Changes in sentence processing as second language proficiency increases. Advances in psychology, 83, 325-336.

McNamara, D. S. (2007). Reading Comprehension Strategies: Theories, Interventions, and Technologies. Mahwah, NJ: Lawrence Erlbaum Associates, Inc. 
Melby-Lervåg, M., \& Lervåg, A. (2014). Reading comprehension and its underlying components in second-language learners: A meta-analysis of studies comparing first-and second-language learners.

Meyer, B. J. F., \& Freedle, R. O. (1984). Effects of discourse type on recall. American Educational Research Journal, 21, 121-143.

Meyers, J., Lytle, S., Palladino, D., Devenpeck, G., \& Green, M. (1990). Think-aloud protocol analysis: An investigation of reading comprehension strategies in fourthand fifth-grade students. Journal of Psychoeducational Assessment, 8, 112-127.

Muijselaar, M. M. L., Swart, N. M., Steenbeek-Planting, E. G., Droop, M., Verhoeven, L., \& de Jong, P. F. (2017). Developmental relations between reading comprehension and reading strategies. Scientific Studies of Reading. 21(3), 194209.

Myers, J., \& Lytle, S. (1986). Assessment of the learning process. Exceptional Children, $53,138-144$.

Nagy, W. (2007). Metalinguistic awareness and the vocabulary-comprehension connection. In R. K. Wagner, A. E. Muse, \& K. R. Tannenbaum (Eds.), Vocabulary acquisition: Implications for reading comprehension (pp. 52-77). New York, NY: Guilford Press.

O’Shea, L. J., Sindelar, P. T., \& O’Shea, D. J. (1985). The effects of repeated readings and attentional cues on reading fluency and comprehension. Journal of Reading Behaviour, 14(2), 129-142.

Pressley, M. (2000). What should comprehension instruction be the instruction of? In M. L. Kamil, P. B. Mosenthal, P. D. Pearson, \& R. Barr (Eds.), Handbook of reading 
research: Volume III (pp. 545-561). Mahwah, NJ: Lawrence Earlbaum Associates, Inc.

Proctor, C. P., Carlo, M., August, D., \& Snow, C. (2005). Native Spanish-Speaking Children Reading in English: Toward a Model of Comprehension. Journal of Educational Psychology, 97(2), 246.

Proctor, C. P., Dalton, B., \& Grisham, D. L. (2007). Scaffolding English language learners and struggling readers in a universal literacy environment with embedded strategy instruction and vocabulary support. Journal of Literacy research, 39(1), 71-93.

Reutzel, D. R. (2016). The Construction-Integration (CI) Model of Text Comprehension. Improving Reading Comprehension through Metacognitive Reading Strategies Instruction, 69.

Reynolds, D., \& Daniel, S. (2017). Toward contingency in scaffolding reading comprehension: Next steps for research. Reading Research Quarterly.

Romney, J. C., Romney, D., \& Menzies, H. (1995). Reading for pleasure in French: A study of the reading habits and interests of French immersion children. Canadian Modern Language Review, 51, 474-511.

Roy, S., \& Galiev, A. (2011). Discourses on bilingualism in Canadian French immersion programs. The Canadian Modern Language Review, 67(3), 351-376.

Saywitz, K. J., \& Snyder, L. (1996). Narrative elaboration: Test of a new procedure for interviewing children. Journal of Consulting and Clinical Psychology, 64(6), $1347-1357$. 
Seipel, B., Carlson, S. E., \& Clinton, V. E. (2017). Do comprehender groups differ? A moment- by-moment analysis of think-aloud protocols of good and poor comprehenders, Reading

Psychology, 38(1), 39-70, doi: 10.1080/02702711.2016.1216489

Snow, C., \& Hoefnagel-Hohle, M. (1978). The critical period for language acquisition: Evidence from second language learning. Child Development, 49, 1114-1128.

Stadtler, M., \& Bromme, R. (2014). The content-source integration model: A taxonomic description of how readers comprehend conflicting scientific information. Processing inaccurate information: Theoretical and applied perspectives from cognitive science and the educational sciences, 379-402.

Stahl, S. (1983). Differential word knowledge and reading comprehension. Journal of Reading Behavior, 15(4), 33-50.

Statistics Canada. 2017. Elementary-Secondary Education Survey for Canada, the Provinces and Territories, 2015/2016. Statistics Canada Catalogue no. 11-001-X. Ottawa. Version updated November 2017. Ottawa. /dailyquotidien/171103/dq171103c-eng.htm (May 23, 2018)

Stevens, E. A., Walker, M. A., \& Vaughn, S. (2017). The effects of reading fluency interventions on the reading fluency and reading comprehension performance of elementary students with learning disabilities: A synthesis of the research from 2001 to 2014. Journal of Learning Disabilities, 50(5), 576-590.

Torgesen, J.K., Wagner, R.K., \& Rashotte, C.A. (1999). Test of Word Reading Efficiency (TOWRE). Austin, TX: Pro-ed. 
Trites, R. L., \& Price, M. A. (1978). Assessment of readiness for primary French immersion. Toronto, Canada: Ontario Ministry of Education.

Uhl-Chamot, A. (2004). Issues in language learning strategy research and teaching. Electronic Journal of Foreign Language Teaching, 1(1), 14-26.

Uhl-Chamot, A., \& El-Dinary, P. B. (1999). Children's learning strategies in language immersion classrooms. The Modern Language Journal, 83(3), 319-338.

van den Broek, P., \& Kremer, K. (2000). The mind in action: What it means to comprehend during reading. In B. M. Taylor, M. F. Graves, \& P. van den Broek (Eds.), Reading for meaning: Fostering comprehension in the middle grades (pp. 1-31). New York: Teachers College Press.

Veenman, M. V. J. (2011). Alternative assessment of strategy use with self-report instruments: A discussion. Metacognition Learning, 6, 205-211.

Wolf, M., \& Katzir-Cohen, T. (2001). Reading fluency and its intervention. Scientific Studies of Reading, 5(3), 211-239.

Yopp, R. E. (1988). Questioning and active comprehension. Questioning Exchange, 2, 231238.

Zwaan, R. A., \& Brown, C. M. (1996). The influence of language proficiency and comprehension skill on situation-model construction. Discourse processes, 21(3), 289-327. 


\section{Appendices}

\section{Appendix A: Parent/Guardian Questionnaire}

1. Todays date (day/month/year):

2. Relationship to participant (please circle): Mother Father Other:

\section{Part A - Background Information}

The following information refers to your CHILD:

3. First Name: Last Name:

4. Date of birth (day/month/year):

5. Gender:

6. Grade:

7. Country of birth:

The following information refers to the PARENTS:

8. Country of birth of GUARDIAN 1:

If not born in Canada, when did guardian 1 come to Canada (year):

List the language known by guardian 1, in order of fluency (most fluent to least fluent):

9. Country of birth of GUARDIAN 2:

If not born in Canada, when did the guardian 2 come to Canada (year): -

List the language known by guardian 2, in order of fluency (most fluent to least fluent): 


\section{Part B - Child's Language}

10. How many years has your child been in French immersion (including this year)?

11. Does your child understand any language other than English and French $\quad$ Yes No

12. If you answered "Yes" to question 11, please specify:

13. Which language did your child first learn? (please circle)

English French Other (please specify):

14. What language is spoken most at home?

\section{English}

French

Other (please specify):

15. How long has your child been enrolled in a French immersion school?

1 year

2 years

3 years

4 or more years

16. How many hours a week does your child read in English at home?

$1-3$

4-6

7-9

$10-12$

14 or more

17. How many hours a week does your child read in French at home?

$1-3$

4-6

7-9

$10-12$

14 or more

18. Please rate how strongly you agree with the following statements by checking the boxes that best apply (English): 


\begin{tabular}{|l|l|l|l|l|l|l|}
\hline $\begin{array}{l}\text { My child learns } \\
\text { English for } \\
\text { communication } \\
\text { purposes }\end{array}$ & & Disagree & Neutral & Agree & $\begin{array}{l}\text { Strongly } \\
\text { Agree }\end{array}$ & $\begin{array}{l}\text { Don't } \\
\text { know }\end{array}$ \\
\hline $\begin{array}{l}\text { My child prefers } \\
\text { to read in English }\end{array}$ & & & & & & \\
\hline $\begin{array}{l}\text { My child is a } \\
\text { good English } \\
\text { reader }\end{array}$ & & & & & & \\
\hline $\begin{array}{l}\text { My child enjoys } \\
\text { reading in English }\end{array}$ & & & & & & \\
\hline
\end{tabular}

19. Please rate how strongly you agree with the following statements by checking the boxes that best apply (French):

\begin{tabular}{|l|l|l|l|l|l|l|}
\hline $\begin{array}{l}\text { My child learns } \\
\text { French for } \\
\text { communication } \\
\text { purposes }\end{array}$ & & Disagree & Neutral & Agree & $\begin{array}{l}\text { Strongly } \\
\text { Agree }\end{array}$ & $\begin{array}{l}\text { Don't } \\
\text { know }\end{array}$ \\
\hline $\begin{array}{l}\text { My child prefers } \\
\text { to read in French }\end{array}$ & & & & & & \\
\hline $\begin{array}{l}\text { My child is a } \\
\text { good French } \\
\text { reader }\end{array}$ & & & & & & \\
\hline $\begin{array}{l}\text { My child enjoys } \\
\text { reading in French }\end{array}$ & & & & & & \\
\hline
\end{tabular}




\section{Appendix B: Peabody Picture Vocabulary Task}

Participant hears "broom" and must identify which picture is being referred to.

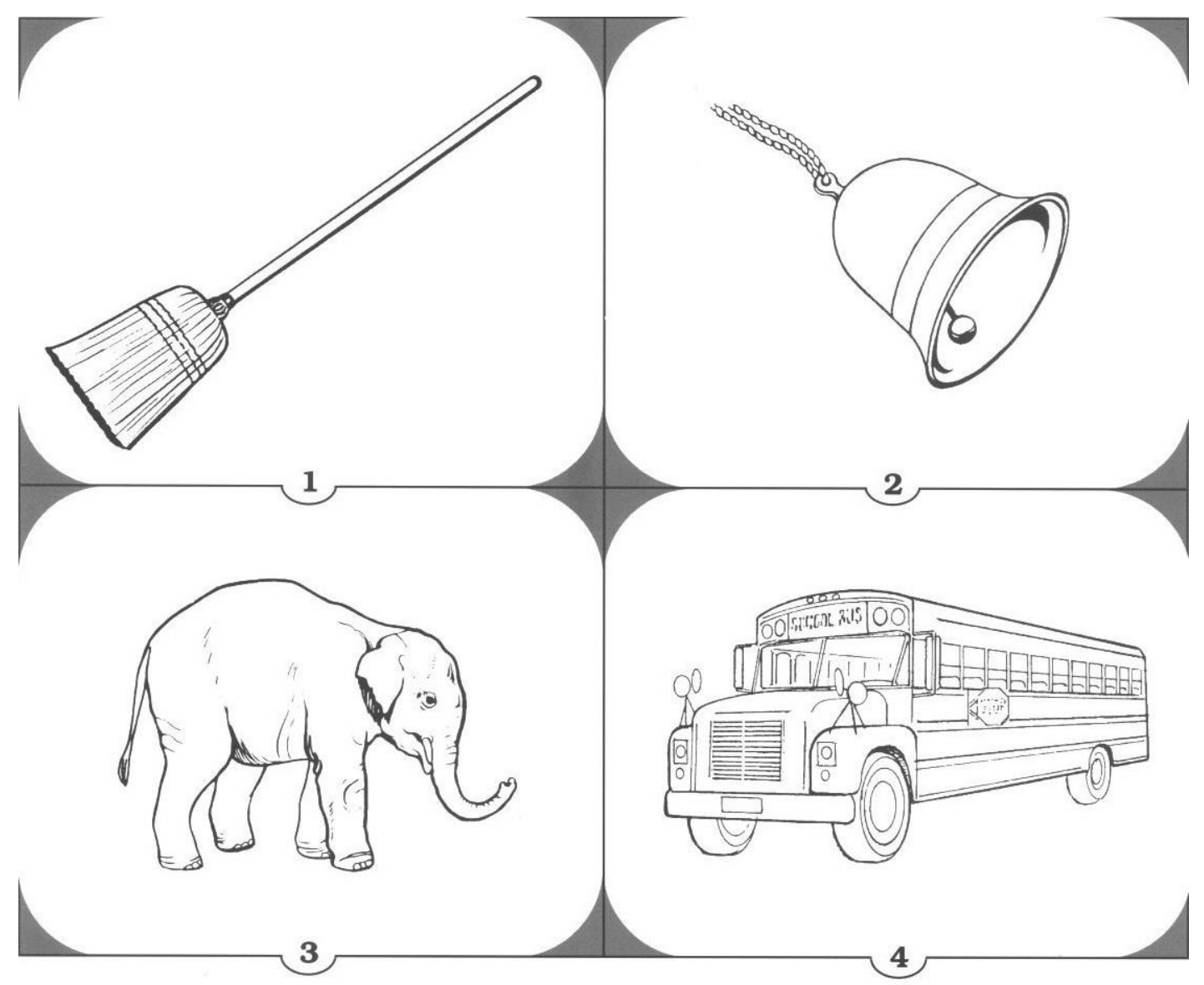




\section{Appendix C: Reading Comprehension Task}

\section{Example English Reading Comprehension Questions}

1. What happened to the fish?

2. Why did the boy look at his grandmother?

3. Why did the boy and his grandmother go fishing?

\section{Example French Reading Comprehension Questions (with translations)}

1. Pourquoi le geai bleu ne pouvait pas t-il boire l'eau? (Why couldn't the blue jay drink the water?)

2. Quelle caractéristiques croyez-vous possède le geai bleu? (What personality traits do you think the blue jay has?)

3. Que faisait la femelle geai bleu pour qu'elle peut boire l'eau? (What did the blue jay do to drink the water?) 
Appendix D: Prompting Statements

\begin{tabular}{|c|c|c|}
\hline Strategy & $\begin{array}{c}\text { English } \\
\text { Prompt }\end{array}$ & $\begin{array}{c}\text { French } \\
\text { Prompt }\end{array}$ \\
\hline Visualizing & $\begin{array}{c}\text { I imagine } \\
\text { that... }\end{array}$ & $\begin{array}{c}\text { J'imagine } \\
\text { que... }\end{array}$ \\
\hline Predicting & $\begin{array}{c}\text { I predict } \\
\text { that... }\end{array}$ & Je Prédit que... \\
\hline Questioning & I wonder if... & $\begin{array}{c}\text { Je me } \\
\text { demande si... }\end{array}$ \\
\hline $\begin{array}{c}\text { Necessary } \\
\text { inference }\end{array}$ & $\begin{array}{c}\text { This means } \\
\text { that.... }\end{array}$ & $\begin{array}{c}\text { Ça veut dire } \\
\text { que... }\end{array}$ \\
\hline $\begin{array}{c}\text { Elaborative } \\
\text { Inference }\end{array}$ & $\begin{array}{c}\text { This makes } \\
\text { me think of... }\end{array}$ & $\begin{array}{c}\text { Ça me fait } \\
\text { penser à }\end{array}$ \\
\hline
\end{tabular}




\section{Appendix E: Ethics Approval}

\section{Research}

\section{Western University Non-Medical Research Ethics Board} NMREB Delegated Initial Approval Notice

Principal Investigator: Dr. Deanna Friesen Department \& Institution: Education, Western University

NMREB File Number: 109030

Study Title: Reading Comprehension and Strategy Use in Fourth and Fifth Grade French Immersion Students

NMREB Initial Approval Date: April 19, 2017 NMREB Expiry Date: April 19, 2018

Documents Approved and/or Received for Information:

\begin{tabular}{|l|l|l|}
\hline Document Name & Comments & $\begin{array}{l}\text { Version } \\
\text { Date }\end{array}$ \\
\hline Western University Protocol & Received April 19,2017 & $2017 / 04 / 19$ \\
\hline $\begin{array}{l}\text { Assent } \\
\text { Caregiver Letter of Information \& }\end{array}$ & & $2017 / 03 / 24$ \\
\hline Instruments & Parental Questionnaire & $2017 / 03 / 24$ \\
\hline Instruments & $\begin{array}{l}\text { English and French Prompting Statements for Think-Aloud - Received } \\
\text { February 9, 2017 }\end{array}$ & \\
\hline Instruments & PPVT Plate - Received February 9, 2017 & \\
\hline Instruments & English TOWRE - Received February 9, 2017 & \\
\hline Instruments & French TOWRE - Received February 9, 2017 & \\
\hline $\begin{array}{l}\text { Data Collection Form/Case Report } \\
\text { Form }\end{array}$ & TOWRE Form - Received February 9, 2017 & \\
\hline Instruments & English and French Passages - Received March 24, 2017 & $2017 / 04 / 10$ \\
\hline Other & Translation Attestation Letter - Received for Information & \\
\hline
\end{tabular}

The Western University Non-Medical Research Ethics Board (NMREB) has reviewed and approved the above named study, as of the NMREB Initial Approval Date noted above.

NMREB approval for this study remains valid until the NMREB Expiry Date noted above, conditional to timely submission and acceptance of NMREB Continuing Ethics Review.

The Western University NMREB operates in compliance with the Tri-Council Policy Statement Ethical Conduct for Research Involving Humans (TCPS2), the Ontario Personal Health Information Protection Act (PHIPA, 2004), and the applicable laws and regulations of Ontario.

Members of the NMREB who are named as Investigators in research studies do not participate in discussions related to, nor vote on such studies when they are presented to the REB.

The NMREB is registered with the U.S. Department of Health \& Human Services under the IRB registration number IRB 0000 p 1. 
Appendix F: Example of Think-Aloud Coding

\begin{tabular}{|c|c|}
\hline Strategy & Definition \\
\hline Summary & $\begin{array}{l}\text { Re-stating specific content - using either } \\
\text { exact or paraphrased wording }\end{array}$ \\
\hline Necessary Inference & $\begin{array}{l}\text { Reference to newly generated knowledge } \\
\text { that is necessary to understanding the text }\end{array}$ \\
\hline Elaborative Inference & $\begin{array}{l}\text { Reference to newly generated knowledge } \\
\text { that is beyond what is necessary to } \\
\text { understand the text }\end{array}$ \\
\hline Prediction & $\begin{array}{l}\text { Reference to possible events or content } \\
\text { upcoming in the text }\end{array}$ \\
\hline Question & $\begin{array}{l}\text { Reference to "why" or "what" an event } \\
\text { has occurred }\end{array}$ \\
\hline Visualization & Reference to a mental image \\
\hline Background Knowledge & $\begin{array}{l}\text { Reference to specific outside knowledge } \\
\text { not found in the text, reference to other } \\
\text { earlier parts of the text or reference to } \\
\text { other texts }\end{array}$ \\
\hline Vocabulary & $\begin{array}{l}\text { Reference made to specific words in the } \\
\text { text or vocabulary difficulty }\end{array}$ \\
\hline Text Structure & $\begin{array}{l}\text { Referring to the type of text (e.g., } \\
\text { exposition, compare \& contrast, narrative, } \\
\text { etc.) }\end{array}$ \\
\hline Sentence Structure & $\begin{array}{l}\text { Reference made to the sentence (e.g., } \\
\text { topic sentence, paragraph sentence, etc.) }\end{array}$ \\
\hline
\end{tabular}




\section{Curriculum Vitae}

Name:

Post-secondary Education and Degrees:

Honours and Awards:

Related Work Experience:
Bailey Frid

University of Western Ontario

London, Ontario, Canada

2012-2016 B.A.

University of Western Ontario

London, Ontario, Canada

2016-2018 M.A.

Province of Ontario Graduate Scholarship 2018-2019

Research Assistantship

2016-2018 
